\title{
Synthesis, antiangiogenesis evaluation and molecular docking studies of 1-aryl-3-[(thieno[3,2-b]pyridin-7-ylthio)phenyl]ureas: Discovery of a new substitution pattern for type II VEGFR-2 Tyr kinase inhibitors
}

\author{
Vera A. Machado a,b,c , Daniela Peixoto ${ }^{a}$, Raquel Costa ${ }^{\mathrm{b}, \mathrm{c}}$, Hugo J. C. Froufe ${ }^{\mathrm{d}}$, Ricardo C. Calhelha ${ }^{\mathrm{a}, \mathrm{d}}$, \\ Rui M. V. Abreu ${ }^{\mathrm{d}}$, Isabel C. F. R. Ferreira ${ }^{\mathrm{d}}$, Raquel Soares ${ }^{\mathrm{b}, \mathrm{c}}$, Maria-João R. P. Queiroz ${ }^{\mathrm{a}, *}$ \\ a Departamento/Centro de Química, Escola de Ciências, Universidade do Minho, Campus de Gualtar, 4710-057 Braga, Portugal \\ ${ }^{\mathrm{b}}$ Departamento de Bioquímica, Faculdade de Medicina, Universidade do Porto, 4200-319 Porto, Portugal \\ ${ }^{\mathrm{C}}$ I3S-Instituto de Investigação e Inovação em Saúde, Porto, Portugal \\ ${ }^{d}$ CIMO-ESA, Instituto Politécnico de Bragança, Campus de Sta. Apolónia, Apartado 1172, 5301-855 Bragança, Portugal
}

\section{A R T I C L E I N F O}

\section{Article history:}

Received 11 June 2015

Revised 1 August 2015

Accepted 12 August 2015

Available online 18 August 2015

\section{Keywords:}

Thienopyridinethioether 1,3-diarylureas

VEGFR-2 tyrosine kinase inhibitors

Enzymatic assays

Molecular docking

HUVECS

Antiangiogenesis assays

Western blotting

\begin{abstract}
A B S T R A C T
The synthesis and biological evaluation of novel 1-aryl-3-[2-, 3- or 4-(thieno[3,2-b]pyridin-7-ylthio)phenyl]ureas 3, 4 and 5 as VEGFR-2 tyrosine kinase inhibitors, are reported. The 1-aryl-3-[3-(thieno[3,2-b]pyridin-7-ylthio)phenyl]ureas $\mathbf{4 a - 4 h}$, with the arylurea in the meta position to the thioether, showed the lowest $\mathrm{IC}_{50}$ values in enzymatic assays $(10-206 \mathrm{nM})$, the most potent compounds $\mathbf{4 d -} \mathbf{4 h}\left(\mathrm{IC}_{50} 10\right.$ $28 \mathrm{nM}$ ) bearing hydrophobic groups $\left(\mathrm{Me}, \mathrm{F}, \mathrm{CF}_{3}\right.$ and $\mathrm{Cl}$ ) in the terminal phenyl ring. A convincing rationalization was achieved for the highest potent compounds $\mathbf{4}$ as type II VEGFR-2 inhibitors, based on the simultaneous presence of: (1) the thioether linker and (2) the arylurea moiety in the meta position. For compounds 4, significant inhibition of Human Umbilical Vein Endothelial Cells (HUVECs) proliferation (BrdU assay), migration (wound-healing assay) and tube formation were observed at low concentrations. These compounds have also shown to increase apoptosis using the TUNEL assay. Immunostaining for total and phosphorylated (active) VEGFR-2 was performed by Western blotting. The phosphorylation of the receptor was significantly inhibited at 1.0 and $2.5 \mu \mathrm{M}$ for the most promising compounds. Altogether, these findings point to an antiangiogenic effect in HUVECs.
\end{abstract}

(c) 2015 Elsevier Ltd. All rights reserved.

\section{Introduction}

The Vascular Endothelial Growth Factor Receptor-2 (VEGFR-2) is a class V Receptor Tyrosine Kinase (RTK), expressed primarily in endothelial cells, and is activated by the specific binding of Vascular Endothelial Growth Factor (VEGF), secreted by endothelial cells and various tumor cells, to the VEGFR-2 extracellular regulatory domain. Once activated, VEGFR-2 undergoes autophosphorylation, triggering signalling pathways leading to endothelial cell proliferation and subsequent tumor angiogenesis that promotes tumor growth and metastasis. ${ }^{1}$ Several small-molecule VEGFR-2 inhibitors have emerged as promising antiangiogenic agents for treatment against a wide variety of cancers and act by competing with adenosine triphosphate (ATP) for the ATPbinding site of the VEGFR-2 intracellular kinase domain, thereby

\footnotetext{
* Corresponding author. Tel.: +351253604378.

E-mail address: mjrpq@quimica.uminho.pt (M.-J.R.P. Queiroz).
}

preventing the intracellular signalling. This leads to angiogenesis, ${ }^{2}$ the sprouting of new capillaries from pre-existing blood vessels, which is a multistep process involving endothelial cell differentiation, proliferation, migration, permeability and tube formation. These assays are used to reproduce the angiogenesis process in vitro. ${ }^{3}$

Most known kinase inhibitors are classified as type I kinase inhibitors, which bind in and around the region occupied by the adenine ring of ATP. ${ }^{4}$ Sunitinib is a classical example of a type I inhibitor and has been approved for the treatment of renal cell carcinomas and gastrointestinal stromal tumors. ${ }^{5}$ On the other hand, type II kinase inhibitors induce the inactive DFG-out conformation of the activation loop, enabling them to occupy the adenine binding site and an adjacent hydrophobic pocket created by this rearrangement. As the residues forming the hydrophobic pocket are less conserved than residues in the adenine pocket, type II inhibitors usually provide a better kinase selectivity when compared to type I inhibitors. ${ }^{4,6}$ 
For VEGFR-2, several type II inhibitors have been reported. These inhibitors occupy the adenine pocket with a suitable ring or ring system that is able to promote 1 to $3 \mathrm{H}$-bonds with the kinase hinge region (Glu917-Cys919); while also occupying the hydrophobic pocket that is available in the DFG-out conformation (Asp1046-Phe1047-Gly1048 for VEGFR-2), with a suitable ring or ring system. A pair of hydrogen bond donating and accepting groups, (usually an urea or a corresponding bioisosteric core) is also present to establish H-bonds with Asp1046 and Glu885. The ring systems occupying both the adenine and the hydrophobic pocket are usually linked via a central ring positioned in an intermediate linker region (Figs. 1 and 2).

A number of type II VEGFR-2 inhibitors, relevant for the discussion of the results are presented in Figure 1. They present a typical pharmacophore model for these inhibitors where a central aryl ring, occupying the linker region, is bound to the ring occupying the adenine pocket via an ether linker (O-linker), while the ring in the hydrophobic pocket is bound to the central ring via an urea group in para position to the O-linker. In the course of molecular modelling studies performed in our group and following a previous study presenting thieno[3,2-d]pyrimidines as VEGFR-2 inhibitors, several observations suggested that alternatives to the O-linker using different configuration patterns, could be explored in an attempt to synthesize original VEGFR-2 inhibitors. ${ }^{10}$ Specifically the use of a thioether linker (S-linker) instead of an ether linker (O-linker) could provide interesting compounds with potent VEGFR-2 inhibition capability and with an alternative profile to the existent type II VEGFR-2 inhibitor scaffolds. Sorafenib was used for comparison with compounds that present similar substituents in the terminal aryl ring located in the hydrophobic pocket.

Herein, we describe an on-going effort to develop novel small-molecule VEGFR-2 inhibitors, based on the thieno[3,2-b]pyridine-7-thioether-1,3-diarylurea scaffold. The synthesis and the VEGFR-2 enzymatic inhibition activity assays of a novel series of 1-aryl-3-[2-, 3- or 4-(thieno[3,2-b]pyridin-7ylthio)phenyl]ureas are presented. Docking simulations were performed to analyze the binding mode of the more potent synthetized compounds. The best compounds identified in enzymatic assays were then tested in VEGF-stimulated Human Umbilical Vein Endothelial Cells (HUVECs). Their proliferation, apoptosis, migration and tube formation, VEGFR-2 expression and activity were examined by BrdU, TUNEL, wound healing and matrigel assays, and by Western blot, respectively.

\section{Results and discussion}

\subsection{Synthesis}

The 7-chlorothieno[3,2-b]pyridine $\mathbf{1}^{11 \mathrm{a}, \mathrm{b}}$ obtained from the commercial 7-hydroxythieno[3,2-b]pyridine and $\mathrm{POCl}_{3}$, reacted with 2-, 3- or 4-aminothiophenol in stoichiometric amounts in DMF at $140{ }^{\circ} \mathrm{C}$ for $2 \mathrm{~h}$ to give only the aminated di(hetero) arylthioethers $\mathbf{2 a - c}$ by nucleophilic aromatic substitution, in very good yields (Scheme 1). These were reacted with differently substituted arylisocyanates in $\mathrm{THF} / \mathrm{CH}_{2} \mathrm{Cl}_{2}$ at room temperature for $12 \mathrm{~h}$, to give the 1-aryl-3-[2-, 3- or 4-(thieno[3,2-b]pyridin-7ylthio)phenyl]ureas $\mathbf{3 a - c}, \mathbf{4 a}-\mathbf{h}$ and $\mathbf{5 a - e}$ in good yields (Scheme 1). The synthesis of compounds $\mathbf{4 d - h}$ bearing hydrophobic groups, was performed after the best results obtained in enzymatic assays (Table 1) for the substitution pattern of compounds $\mathbf{4 a - 4 c}$. For compounds $\mathbf{5}$, based also in the results of enzymatic assays (Table 1 ) that were not so good then for series 4, only compounds with substituents that are present in Sorafenib (Fig. 1) $\mathrm{CF}_{3}$ and/or $\mathrm{Cl}$, were prepared in order to evaluate their effects.

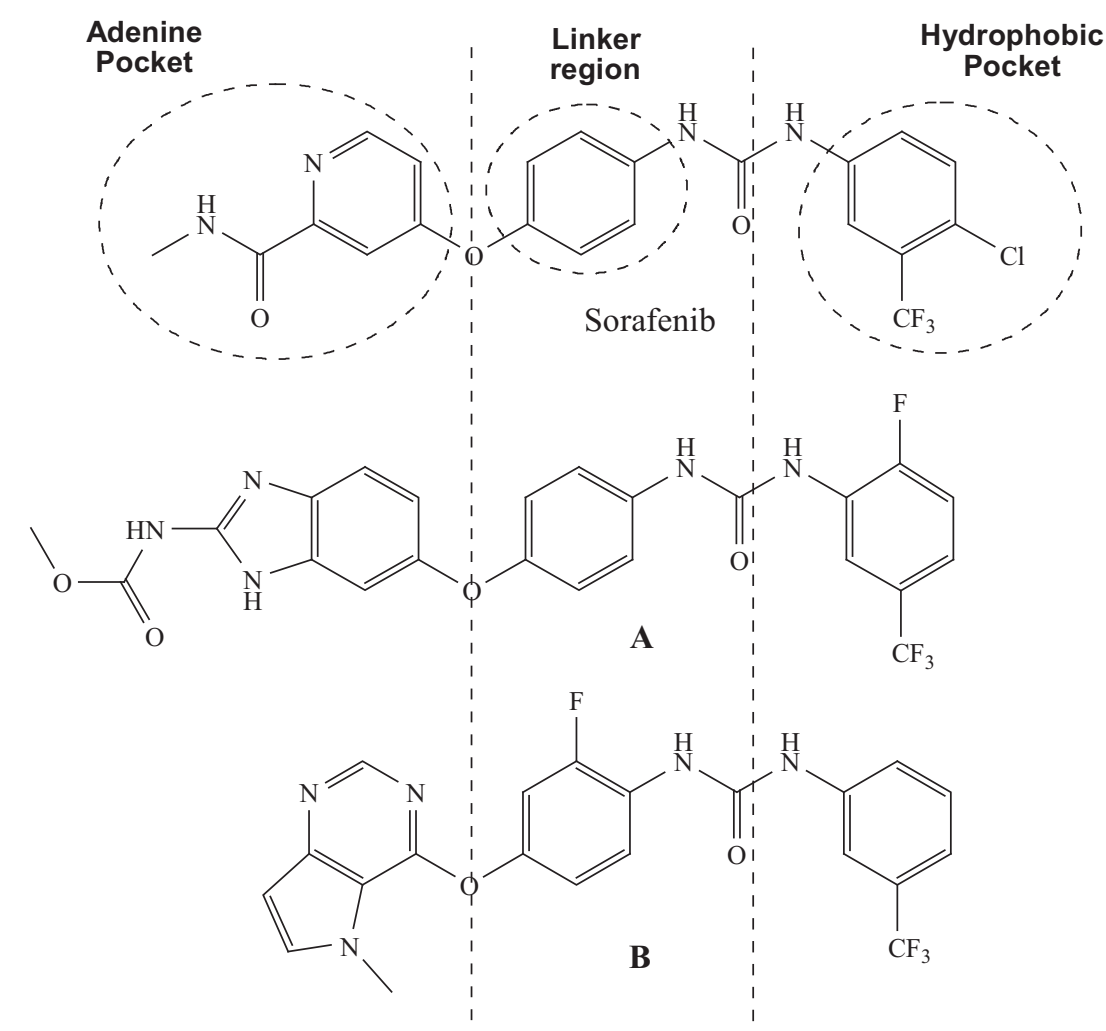

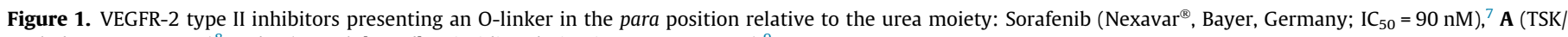
Tsukuba $\left.\mathrm{IC}_{50}=3.5 \mathrm{nM}\right)^{8}$ and $\mathbf{B}$ (pyrrolo[3,2-d]pyrimidine derivative; $\mathrm{IC}_{50}=6.2 \mathrm{nM}$ ). ${ }^{9}$ 


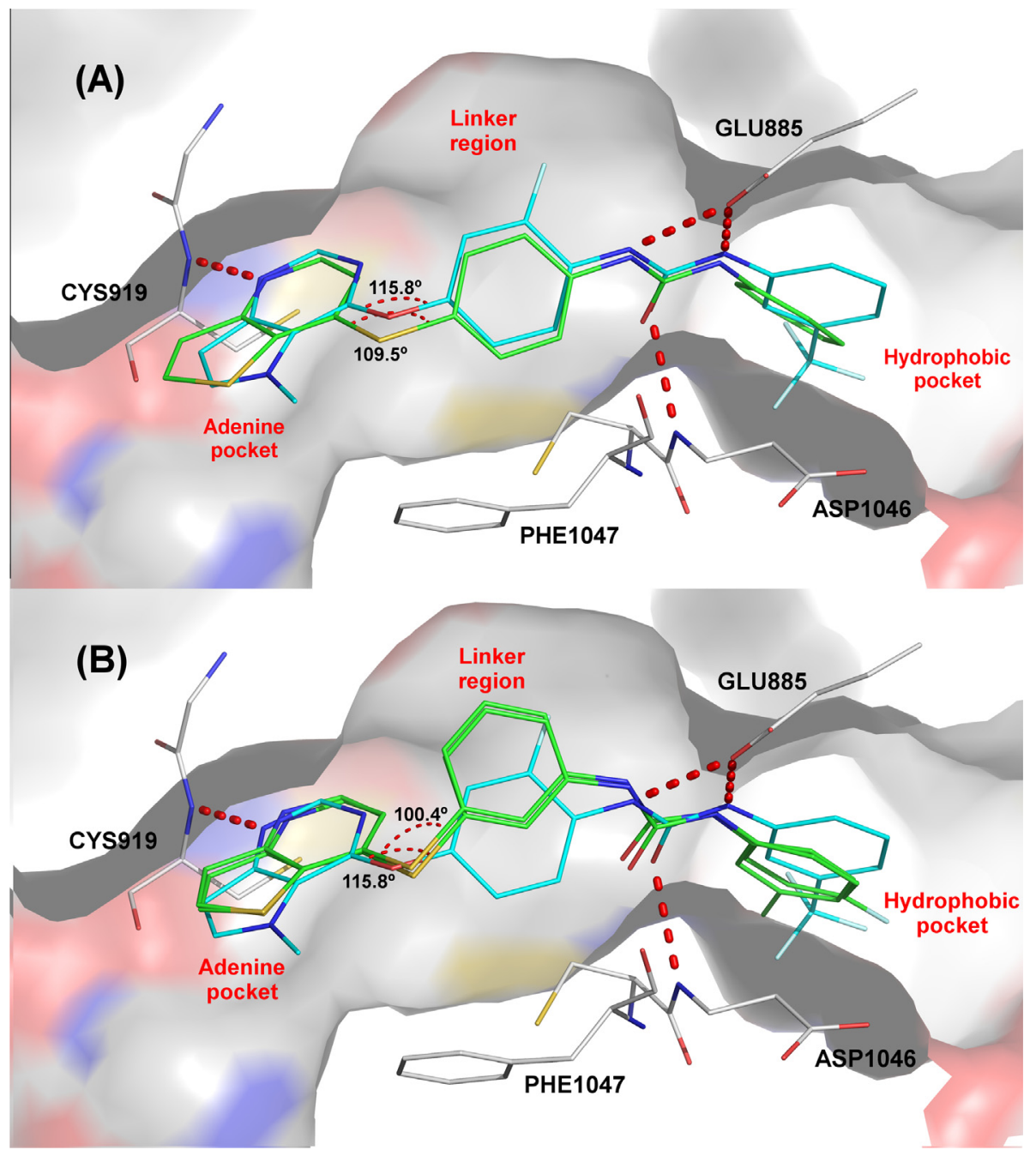

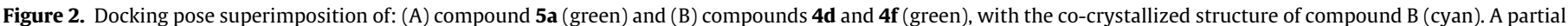

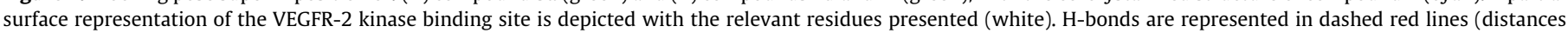
between 2.8 and $3.4 \AA$ A). Structures were prepared using PyMOL. ${ }^{18}$

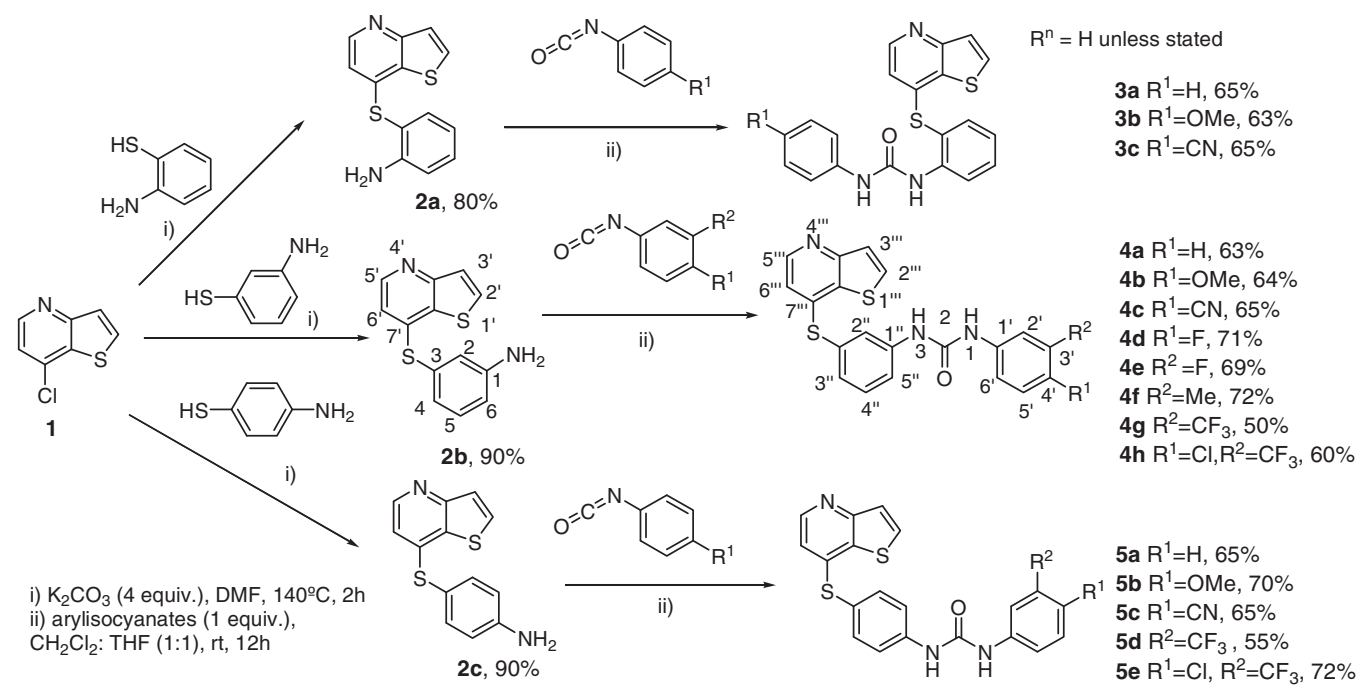

Scheme 1. Synthesis of the 2-, 3- or 4-(thieno[3,2-b]pyridin-7-ylthio)anilines 2a-c and of the 1-aryl-3-[2-, 3- or 4-(thieno[3,2-b]pyridin-7-ylthio)phenyl]ureas 3-5. 
Table 1

VEGFR-2 inhibition activity of compounds $\mathbf{3 a - c}, \mathbf{4 a - h}$ and $\mathbf{5 a - e}$

\begin{tabular}{|c|c|}
\hline Compound & $\begin{array}{l}\text { VEGFR-2; } \mathrm{IC}_{50}{ }^{\mathrm{a}} \text { (using } 10 \mu \mathrm{M} \text { of ATP) } \\
(\mathrm{nM})\end{array}$ \\
\hline 3a & $>100,000$ \\
\hline 3b & $>100,000$ \\
\hline 3c & $>100,000$ \\
\hline $4 a$ & 94 \\
\hline $4 b$ & 107 \\
\hline 4c & 206 \\
\hline $4 d$ & 10 \\
\hline $4 e$ & 28 \\
\hline 4f & 11 \\
\hline $4 \mathrm{~g}$ & 15 \\
\hline $4 h$ & 16 \\
\hline $5 \mathbf{a}$ & 1160 \\
\hline $5 \mathbf{b}$ & 1390 \\
\hline $5 c$ & 8360 \\
\hline 5d & 988 \\
\hline $5 \mathbf{e}$ & 1947 \\
\hline $\begin{array}{l}\text { Staurosporine }{ }^{\mathrm{b}} \text { (enzymatic kit } \\
\text { control) }\end{array}$ & 6 \\
\hline
\end{tabular}

a Each $\mathrm{IC}_{50}$ determination is a result of at least four separate determinations.

b Staurosporine experimental VEGFR-2 $\mathrm{IC}_{50}=7 \mathrm{nM} .^{16}$

\subsection{Enzymatic inhibition and structure activity-relationship}

Compounds 3a-c, 4a-c and $\mathbf{5 a - c}$ were first synthetized and subsequently evaluated for their ability to interact with the VEGFR-2 kinase domain (Table 1), using an enzymatic FRET-based assay. ${ }^{12}$ The three series differ in the position of the arylurea scaffold; with compounds 3, 4 and 5 bearing it in the ortho, meta and para-position relative to the thioether linker, respectively. Compounds 4a-c displayed the highest enzyme inhibition potency with $\mathrm{IC}_{50}$ values of 94,107 and $206 \mathrm{nM}$, respectively; whereas compounds 5a, 5b displayed either moderate, 1160 and $1390 \mathrm{nM}$, respectively, or 5c weak VEGFR-2 inhibition activity, $8360 \mathrm{nM}$; compounds $\mathbf{3 a}-\mathbf{c}$ were inactive. These findings are surprising as compounds 5 present similarities with known VEGFR-2 inhibitors with the arylurea moiety in the para position, ${ }^{8-10,13-15}$ including the drug Sorafenib (Fig. 1). ${ }^{7}$ Instead, compounds $4 a-4 c$ with the arylurea group in the meta position, were an order of magnitude more potent. The arylurea in the meta position is usually not considered as a promising feature and the studies using different scaffolds as potential VEGFR-2 inhibitors always explore the arylurea in the para position ${ }^{7-10,13-15}$ although presenting an O-linker instead of a S-linker.

In fact, considering the number of scaffolds with VEGFR-2 inhibitory activity already published, it is surprising that a S-linker in meta position relative to the urea moiety was not explored before by others. The explanation is probably inherent to the rational of the drug design process where only one feature is explored at a time. We have found at least two studies performed by Hasegawa et $a .^{8}$ and Oguro et al. $^{9}$ where the importance of the O/S linker atom and the meta/para position relative to the urea moiety was analyzed in a series of benzimidazole and pyrrolo[3,2- $d]$ pyrimidine derivatives, respectively. These compounds explore the same VEGFR-2 binding mode with the best clinical candidate provided by each study presented as compound A (benzimidazole) and $\mathrm{B}$ (pyrrolo[3,2-d]pyrimidine derivative) (Fig. 1). In both studies the $\mathrm{O} / \mathrm{S}$-linker was investigated only in para position relative to the urea moiety, with the S-linker always providing less potent compounds and being discarded for further synthesis. In fact the presence of a S-linker, when compared to similar compounds with an O-linker, lowered the VEGFR-2 inhibition potency by 3 -fold and 20-fold for the benzimidazole and pyrrolo[3,2-d]pyrimidine derivatives, respectively. Similarly, the meta/para position relative to the urea was only investigated using an O-linker, with the meta position always providing less potent compounds and thus also being discarded for further synthesis. Also compounds with the O-linker and urea in the meta position lowered the activity by 6fold and 55-fold for the benzimidazole and pyrrolo[3,2-d]pyrimidine derivatives, respectively, when compared to compounds with the O-linker in the para position relative to the urea. As far as our knowledge, this thieno[3,2-b]pyridine series is the first that presents compounds with a S-linker in the meta position relative to the urea moiety with potent inhibition activity against VEGFR-2. This study provides a new insight in the field as this substitution pattern was not previously investigated and has been thought to be of low potency.

Typically, for type II VEGFR-2 inhibitors, the terminal aryl ring that occupies the hydrophobic pocket is functionalized with hydrophobic substituent groups, the most frequent being methyl groups or halogen atoms in meta or para position, although other substitution pattern is observed (Fig. 1). Based on this information compounds $\mathbf{4 d}-\mathbf{h}$ were synthetized in an attempt to obtain more potent VEGFR-2 inhibitors than compounds $\mathbf{4 a - 4 c}$. Compounds $\mathbf{4 d}$ with a $\mathrm{F}$ atom in the para position or $\mathbf{4 e}$ with a $\mathrm{F}$ in the meta position, $\mathbf{4 f}$ with a methyl group, $\mathbf{4 g}$ with a $\mathrm{CF}_{3}$ both in the meta position and $4 \mathrm{~h}$ with $\mathrm{CF}_{3}$ in meta and $\mathrm{Cl}$ in the para position, relative to the urea moiety, were the most potent VEGFR-2 inhibitors in enzymatic assays with $\mathrm{IC}_{50}$ values of $10,28,11,15$ and $16 \mathrm{nM}$, respectively (Table 1 ). These values are in line with the most potent VEGFR-2 inhibitor agents and pending further analysis, compounds $\mathbf{4 d}-\mathbf{h}$ can already be considered as potential leads for new antiangiogenic compounds. This increase of potency in one order of magnitude with hydrophobic substituents in the terminal aryl ring provides evidence that the latter in fact occupies the hydrophobic pocket in a similar fashion to other known type II inhibitors.

Although compounds 5 have given high $\mathrm{IC}_{50}$ values it was decided to prepare compounds in this series with substituents $\mathrm{CF}_{3}$ and/or $\mathrm{Cl}$ present in the Sorafenib, but the $\mathrm{IC}_{50}$ values did not significantly decreased (Table 1 ).

In order to explain the VEGFR-2 inhibitory activity of compounds 4 , we set out to investigate in detail the binding mode of compounds 4d and $\mathbf{4 f}$ and 5a by performing molecular docking studies.

\subsection{Molecular docking simulations}

To better understand the structural rational behind the VEGFR2 inhibition potency observed for the synthesized compounds, molecular docking simulations were performed using AutoDock4 software. The VEGFR-2 kinase domain crystal structure with PDB code: 3 VHE was selected because it presented a co-crystallized inhibitor (compound B, Fig. 1) with the closest structure compared to the compounds prepared in this work. For a suitable comparison, compounds 5a and compounds $\mathbf{4 d}$ and $\mathbf{4 f}$ were docked against the selected structure and then superimposed with the experimental structure of compound B (Fig. 2A and B). The other compounds of series $\mathbf{5}$ were also docked and the obtained docking poses were a near perfect superimposition to compound 5a docking pose. So for clearance of representation on Figure 2A only compound $\mathbf{5 a}$ was used as it is the simplest, without substitution in the terminal aryl ring.

For the less potent compound 5a a similar binding mode pattern to compound B was observed (Fig. 2A). In both compounds the urea moiety forms two H-bonds with the Glu885 carboxyl group, and the $\mathrm{C}=\mathrm{O}$ urea group forms a third $\mathrm{H}$-bond with the backbone $\mathrm{N}-\mathrm{H}$ of Asp1046. The thieno[3,2-b]pyridine moiety is docked in adenine pocket with a near perfect superimposition to the pyrrolo[3,2-d]pyrimidine ring of compound $\mathbf{B}$, and both rings are positioned in order to form the critical H-bond with the 
Cys919 backbone N-H group. The central aryl group is docked on the linker region and the terminal aryl ring on the hydrophobic pocket (Fig. 2A). However a more detailed inspection of compound 5a docking pose gives us some insights on why the S-linker in the para position is probably less favored compared to the O-linker in the same position. In fact, in order to accommodate the network of critical $\mathrm{H}$-bonds and allow a correct pocket occupation of the ring systems, the S-linker was stretched to a $109.5^{\circ}$ angle when the more stable value for a S-linker angle is approximately $90^{\circ}$ (Fig. 2A). The co-crystallized structure of compound B on the other hand presents a O-linker angle of $115.8^{\circ}$ that is closer to the ideal $110^{\circ}$ angle. ${ }^{17}$ This widening of the S-linker is energetically unfavorable and probably explain the much lower potency of compound 5a $\left(\mathrm{IC}_{50}=1166 \mathrm{nM}\right)$ compared to compound $\mathbf{B}\left(\mathrm{IC}_{50}=6.2 \mathrm{nM}\right)$. It is likely that there may be a protein shifting in the active site to relieve this very high energy situation and the docking presented in Figure 2A is likely to be an approximation of the actual interaction between compound $\mathbf{5 a}$ and the active site.

For the most potent compounds $4 \mathbf{d}$ and $\mathbf{4 f}\left(\mathrm{IC}_{50}\right.$ of 10 and $11 \mathrm{nM}$, respectively) the same superimposition with compound $\mathbf{B}$ is also presented (Fig. 2B). A closer inspection of the docked poses shows that, due to the presence of the S-linker in the meta position relative to the urea group, the central aryl ring is placed deeper inside the linker region, when compared to compound B. The S-linker sharper angle $\left(100.4^{\circ}\right)$ is close to the ideal $90^{\circ}$ angle and now appears to work in favor of increasing VEGFR-2 inhibitory potency by enabling a more favored occupation of the linker region by the central aryl ring. In fact this ring is superimposed with the $\mathrm{F}$ atom of compound $\mathbf{B}$, further evidence that this linker region occupation pattern is possible and probably favored.

The higher inhibition potency of compound $\mathbf{4 d}$ with an $\mathrm{F}$ atom in the para position and $\mathbf{4 f}$ with a methyl group in the meta position, relative to the urea moiety, when compared to compound 4a with no substitution, is also widely observed for other known type II inhibitors (Fig. 1) and it is due to a better occupation of the hydrophobic pocket. ${ }^{13-15}$ This observation further demonstrates that the predicted docked poses are probably correct.

\subsection{Cell culture assays}

The best compounds in enzymatic assays (4a-h) against VEGFR-2 tyrosine kinase domain were examined in cell culture viability and proliferation assays using HUVECs stimulated by VEGF. Cell viability was first analyzed by MTS assay (Fig. 3). The effects of compounds $4 \mathbf{a}-\mathbf{f}$ at $0.1-10 \mu \mathrm{M}$ on HUVECs viability are shown in Figure 3A. Cell viability was reduced by each compound at a dose-dependent manner, reaching statistical significance at the concentration of $5.0 \mu \mathrm{M}$ or higher. The effects of compounds $\mathbf{4 g}$ and $\mathbf{4 h}$ on HUVECs viability were analyzed. Given the similarity of the hydrophobic chemical pattern substitution of Sorafenib, this drug was used as a positive control for compounds $\mathbf{4 g}$ and $\mathbf{4 h}$, these two compounds being used at $1.0-10 \mu \mathrm{M}$, the concentrations established for Sorafenib in cell culture assays (Fig. 3B). Compound $\mathbf{4 g}$ significantly reduced the cell viability at $10 \mu \mathrm{M}$, while compound $4 \mathrm{~h}$ did it at $2.5,5.0$ and $10 \mu \mathrm{M}$. Nevertheless, they only affected more than $50 \%$ cell viability $(\mathbf{4 g}=44 \%, \mathbf{4 h}=26 \%)$, revealing a cytotoxic effect on HUVECs for the highest concentration tested $(10 \mu \mathrm{M})$, as Sorafenib (18\%). Altogether, these findings reveal that every compound was able to decrease HUVECs viability. Though, compounds $\mathbf{4 g}$ and $\mathbf{4 h}$ presented significant reductions at lower concentrations.

A proliferation assay was then assessed using the BrdU incorporation, a thymidine analogue which incorporates into DNA of dividing cells (Fig. 4). Compounds $4 a\left(R^{1}=H\right), \mathbf{4 c}\left(R^{1}=C N\right)$, and $4 \mathbf{f}\left(R^{2}=\mathrm{Me}\right)$ showed a statistical significant antiproliferative effect at $1.0 \mu \mathrm{M}$ (Fig. $4 \mathrm{~A}$ ) without significantly affecting cell viability
(Fig. 3A). Remarkably, compounds $4 \mathbf{b}\left(\mathrm{R}^{1}=\mathrm{OMe}\right), \mathbf{4 d}\left(\mathrm{R}^{1}=\mathrm{F}\right)$ and $4 e\left(R^{2}=F\right)$ showed a higher antiproliferative effect, revealing a statistical significant cell proliferation decrease at $0.5 \mu \mathrm{M}$ (Fig. 4A) without affecting cell viability (Fig. $3 \mathrm{~A})$. Compounds $\mathbf{4 g}\left(\mathrm{R}^{2}=\mathrm{CF}_{3}\right)$, 4h $\left(\mathrm{R}^{1}=\mathrm{Cl} ; \mathrm{R}^{2}=\mathrm{CF}_{3}\right)$ significantly inhibited proliferation of HUVECs at 2.5 and $5.0 \mu \mathrm{M}$, without high cytotoxic effect. Sorafenib is known to prevent cell growth in endothelial cells. ${ }^{7}$ Interestingly enough, compounds $\mathbf{4 g}$ and $\mathbf{4 h}$ exhibit, thus, a more noteworthy effect than Sorafenib, which only significantly affected proliferation of these cells at $5.0 \mu \mathrm{M}$ (Fig. 4B).

These results showed that all the tested compounds considerably inhibit VEGF-stimulated HUVECs proliferation in a dose-dependent manner at low concentrations.

\subsection{Effect on apoptosis}

The induction of apoptosis is a therapeutic approach for cancer treatment. Several anticancer drugs, including some VEGFR-2 inhibitors can promote apoptosis. ${ }^{19}$ The effect of compounds $\mathbf{4 a - h}$ on cell apoptosis was then evaluated by TUNEL assay (Fig. 5). Concentrations of $0.1-1.0 \mu \mathrm{M}$ of compounds $\mathbf{4 a - 4 f}$ were used in the subsequent assays due to their antiproliferative effect without cytotoxic effect at these concentrations (Fig. 5A). An increase in apoptosis was observed when HUVECs were incubated with increasing concentrations of the tested compounds for $24 \mathrm{~h}$, reaching statistical significance only for $\mathbf{4 b} \mathbf{b} \mathbf{4 d}$ at the highest concentration tested $(1.0 \mu \mathrm{M})$ in comparison to control. These findings indicate that besides the effects of these three compounds in HUVECs proliferation, they also induce apoptosis. Compounds $\mathbf{4 a}$, $\mathbf{4 e}$ and $\mathbf{4 f}$ increased apoptosis in a dose-dependent manner, but not with statistical significance (Fig. 5A).

For compounds $\mathbf{4 g}$ and $\mathbf{4 h}$, the concentrations selected for this and the following assays were 2.5 and $5.0 \mu \mathrm{M}$ since they are the lowest concentrations of these compounds that have shown an antiproliferative effect without being cytotoxic to HUVECs (Figs. 3B and 4B). As shown in Figs. 5B, 4g and h significantly increase apoptosis at $5.0 \mu \mathrm{M}$. Many studies report that Sorafenib induces apoptosis. ${ }^{19}$ The findings in this study reveal that compounds $\mathbf{4 g}$ and $\mathbf{4 h}$ exhibited a higher effect than Sorafenib in apoptosis.

\subsection{Effect on HUVECs migration}

Cell migration is an essential feature for endothelial cells in angiogenesis. ${ }^{20}$ Therefore, we next examined the effect on the HUVECs chemotactic motility of the most promising compounds 4d-4h, according to the previous results on HUVECs viability and proliferation, by wound-healing assay (Fig. 6). The results show that compounds 4d-4f significantly inhibited VEGF-induced HUVECs migration in a dose-dependent manner ranging from $0.1 \mu \mathrm{M}$ to $5.0 \mu \mathrm{M}$ (Fig. $6 \mathrm{~A}$ ). Treatment with compounds $\mathbf{4 g}$ and 4h significantly inhibited HUVECs migration at concentrations of $2.5 \mu \mathrm{M}$ and $5.0 \mu \mathrm{M}$ showing a similar effect to Sorafenib (Fig. 6B). These findings regarding Sorafenib effect in endothelial cell migration were corroborated by previous studies in the literature. ${ }^{21}$ Nonetheless, incubation with compound $\mathbf{4 h}$ was more effective than Sorafenib, implying a better inhibitory role in this relevant angiogenic step.

\subsection{Effect on HUVECs tube formation}

To elucidate the possible mechanisms of angiogenesis inhibition, tube formation ability of endothelial cells, which is also a critical step in the angiogenic process, was assessed in HUVECs. As shown in Figure 7, HUVECs plated on a Matrigel coated plate formed capillary-like structures in cells cultured in the absence 

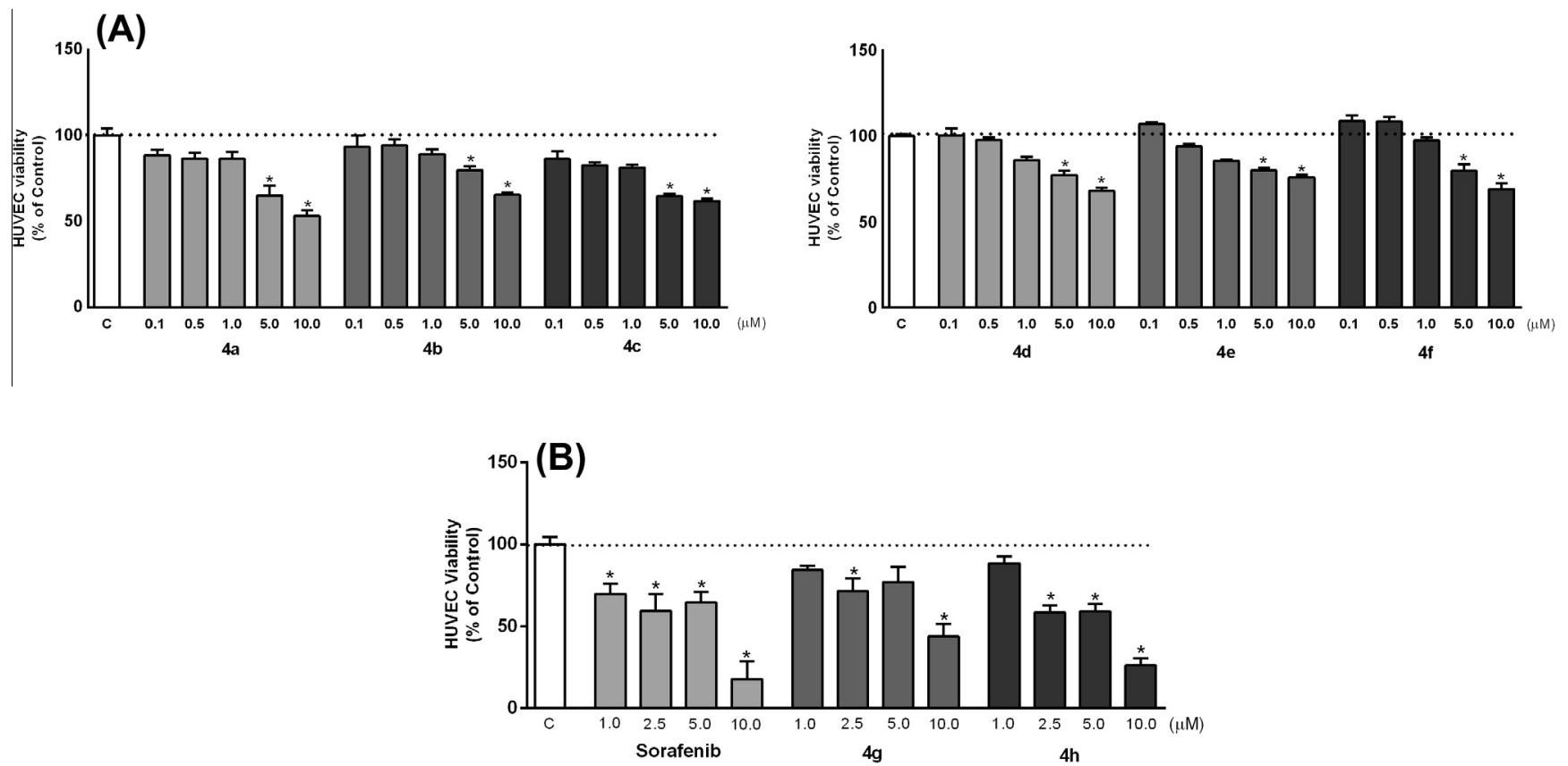

Figure 3. Evaluation of the HUVECs viability effects of compounds 4a-h and Sorafenib on VEGF-stimulated HUVECs by MTS assay. (A) HUVECs viability upon treatment with compounds 4a-f at concentrations of 0.1-10 $\mu \mathrm{M}$. (B) HUVECs viability upon treatment with compounds $\mathbf{4 g}$, $4 \mathrm{~h}$ and Sorafenib at 1.0-10 $\mu \mathrm{M}$. Results were obtained after $24 \mathrm{~h}$, and are expressed as percentage of control ( $0.1 \%$ DMSO with $60 \mathrm{ng} / \mathrm{mL}$ VEGF) as means \pm SEM of at least three independent experiments, performed in triplicate. " $p<0.05$ versus control.
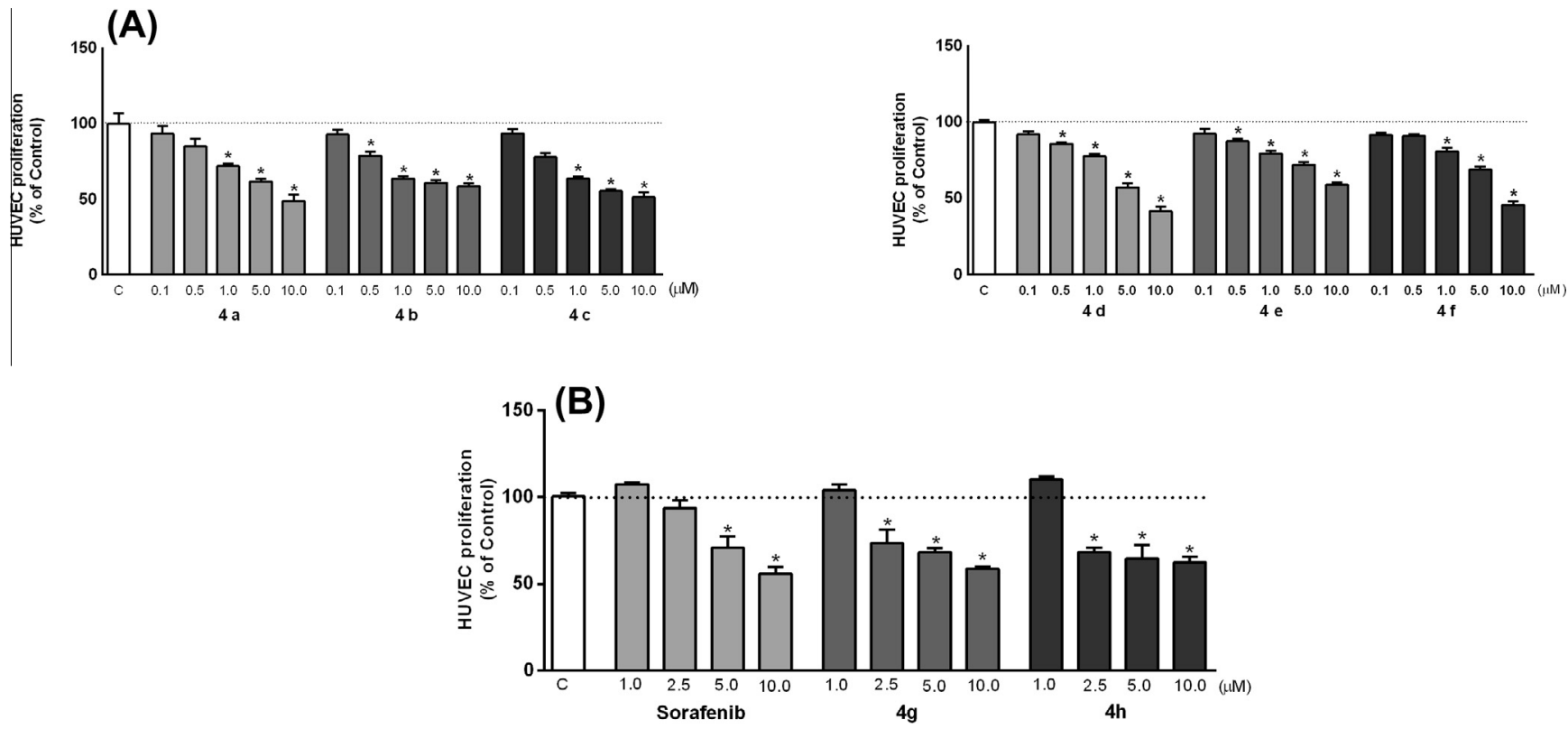

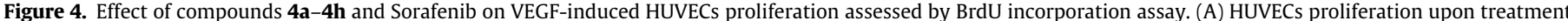

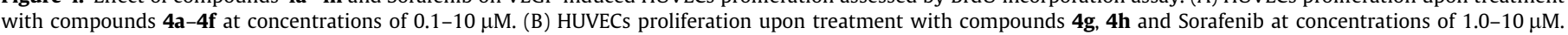

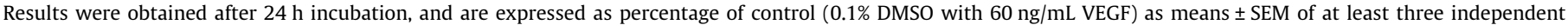
experiments, performed in triplicate. ${ }^{*} p<0.05$ versus control.

of compounds (control). A significant decrease of these structures was observed whenever cells were incubated with compounds 4d-4f at concentrations of $0.5-5.0 \mu \mathrm{M}$, in a dose-dependent manner (Fig. 7A). In the presence of compounds $\mathbf{4 g}$, $\mathbf{4 h}$ or Sorafenib at concentrations of 2.5 and $5 \mu \mathrm{M}$, tube formation of HUVECs was significantly reduced (Fig. 7B), except for $\mathbf{4 g}$ at $2.5 \mu \mathrm{M}$. This assay is a hallmark of angiogenesis evaluation in vitro. Interestingly, prevention of this process was also accomplished by every compound tested in the present study in a significant manner, implying thus, the important antiangiogenic role of these molecules.

\subsection{Effect on VEGFR-2 phosphorylation}

The results presented herein were obtained in VEGF stimulated HUVECs cultures, implying that the compounds analyzed were able to exert their effects by interfering with VEGF signalling 

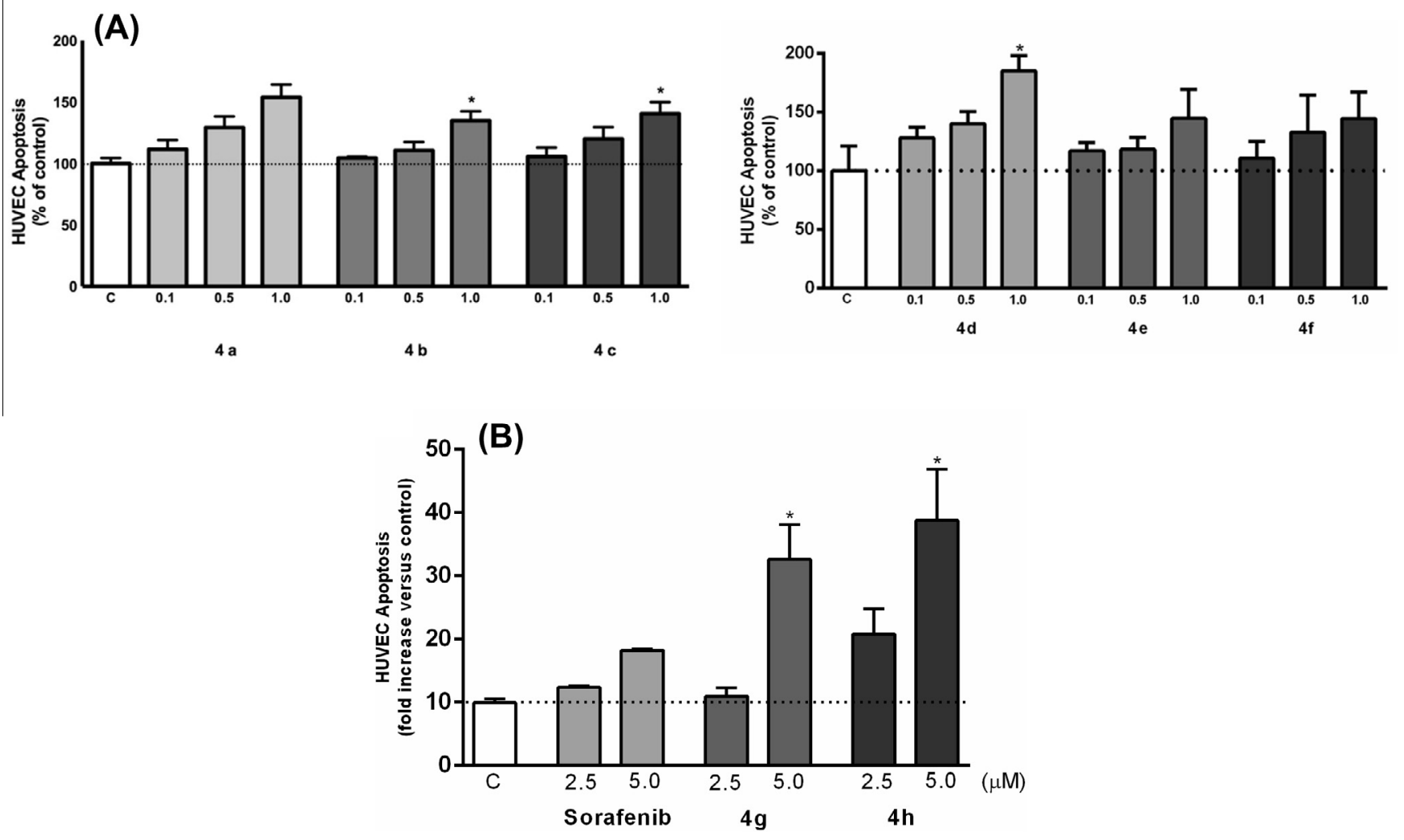

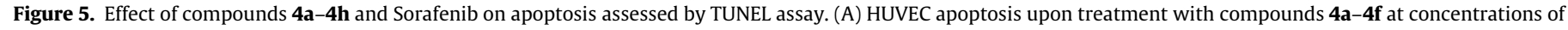

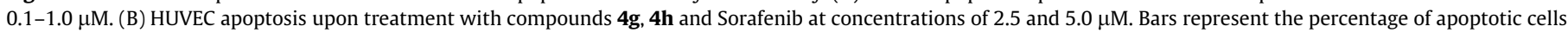

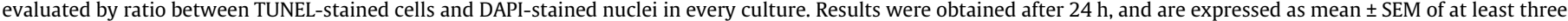
independent experiments. " $p<0.05$ versus control.

pathway. To confirm this hypothesis, a Western blotting assay for total and phosphorylated (active) VEGFR-2 was performed. At $1.0 \mu \mathrm{M}$ compounds $\mathbf{4 a}, \mathbf{4 b}$ and $\mathbf{4 d}-\mathbf{4 f}$ significantly decreased the active form of VEGFR-2 (Fig. 8A-D) ( ${ }^{*} p<0.05$ vs control). Moreover, compounds $\mathbf{4 g}$ and $\mathbf{4 h}$, at concentrations of 2.5 and $5.0 \mu \mathrm{M}$, significantly decreased VEGFR-2 phosphorylation, presenting a better effect than Sorafenib (Fig. 8E and F).

VEGF signalling pathway through the VEGFR-2 tyrosine kinase phosphorylation displays a crucial role in angiogenesis, namely, enhancing endothelial cell survival, proliferation and migration. ${ }^{22}$ Many other signalling pathways are involved in angiogenesis, nevertheless, VEGF signalling, an angiogenic surrogate pathway, which is involved in the whole multistep process, from cell proliferation, migration, invasiveness capacity, anastomosis, ending up in the assembly of newly formed vascular structures. Therefore, we believe that inhibiting this pathway is an effective approach against angiogenesis.

\section{Conclusion}

In conclusion the synthesis of new 1-aryl-3-[2-, 3- or 4-(thieno[3,2-b]pyridin-7-ylthio)phenyl]ureas $\mathbf{3 , 4}$ and $\mathbf{5}$ in overall good yields is reported. Compounds $\mathbf{4}$, with the arylurea in the meta position relative to the S-linker, showed to be the most potent phosphorylation tyrosine kinase VEGFR-2 inhibitors, presenting $\mathrm{IC}_{50}$ values between 10 and $206 \mu \mathrm{M}$ in enzymatic assays, depending on the substituents on the terminal phenyl ring. To better understand these results, molecular docking simulations were performed. The predicted docked poses were analyzed in detail and a plausible explanation for compounds $\mathbf{4}$ and in particularly for $\mathbf{4 d}$ and $\mathbf{4 f}$ potency ( 10 and $11 \mathrm{nM}$ ) was obtained based on the simultaneous presence of a S-linker and the arylurea moiety in the meta position as a new substitution pattern for the type II VEGFR-2 inhibitors. The importance of hydrophobic substituents in $\mathbf{4 d}$ and $\mathbf{4 f}(\mathrm{F}$ and Me, respectively) in the terminal phenyl ring is also highlighted. These chemical features place the thieno[3,2-b]pyridine and the terminal aryl ring in close superimposition to a pyrrolo [3,2-d]pyrimidine derivative, type II co-crystallized VEGFR-2 ligand. Compounds $\mathbf{4 g}$ an $\mathbf{4 h}$ with pattern substitution closer to Sorafenib showed also low $\mathrm{IC}_{50}$ values (15 and $16 \mathrm{nM}$ ).

Our results showed that compounds 4 affect various steps of angiogenesis including endothelial cell proliferation, apoptosis, migration and capillary structure formation in a dose dependent manner.

In the present study we found that compounds $\mathbf{4}$ significantly block the tyrosine kinase phosphorylation of VEGFR-2, as observed by Western blotting in vitro, suggesting these compounds as potent VEGFR-2 inhibitors.

As far as our knowledge the S-linker in the meta position relative to the urea moiety constitutes a new substitution pattern that has not been disclosed in other known type II VEGFR-2 inhibitors.

This can thus be regarded as an interesting feature for the synthesis of new compounds with higher VEGFR-2 inhibitory activity and also for other scaffolds exploring the same VEGFR-2 binding conformation.

Although future studies, namely using animal models, are crucial, overall, our findings support the hypothesis that all these molecules are potent antiangiogenic agents. 
(A)

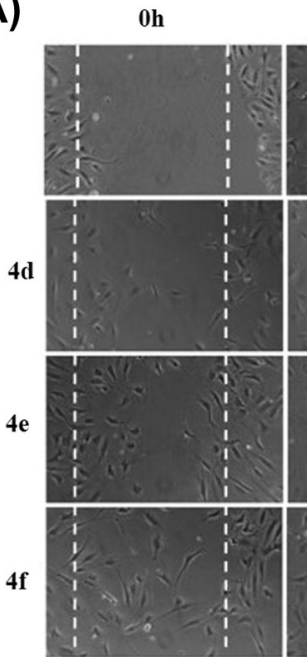

0.1
C

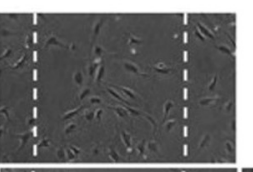

(B)

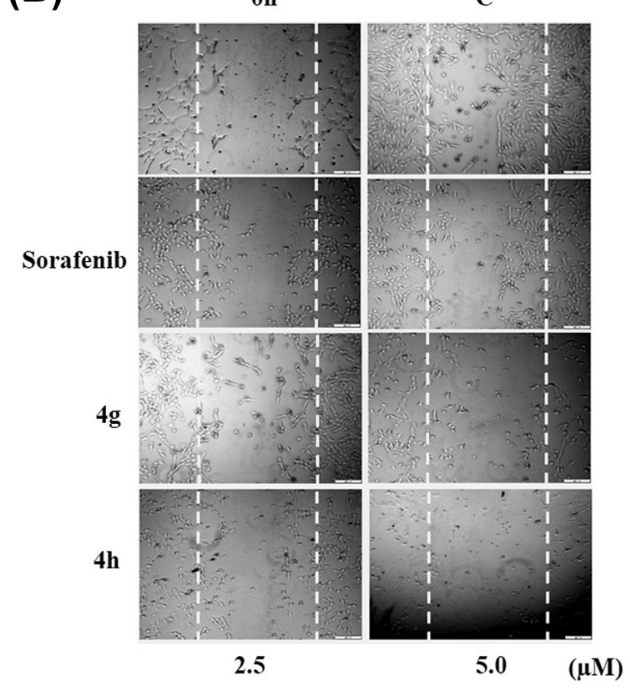

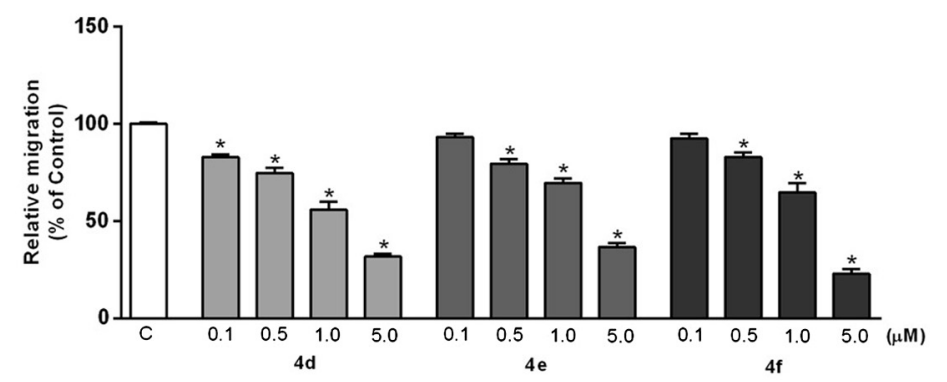

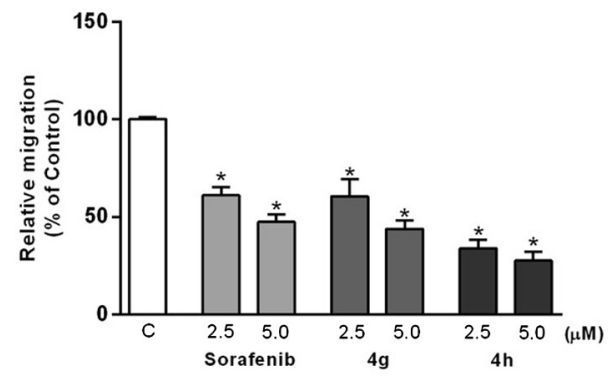

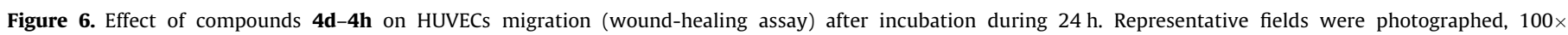

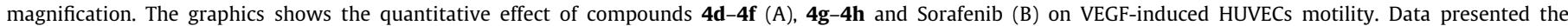
percentage of control, as mean \pm SEM of three independent experiments. $p<0.001$ versus control.
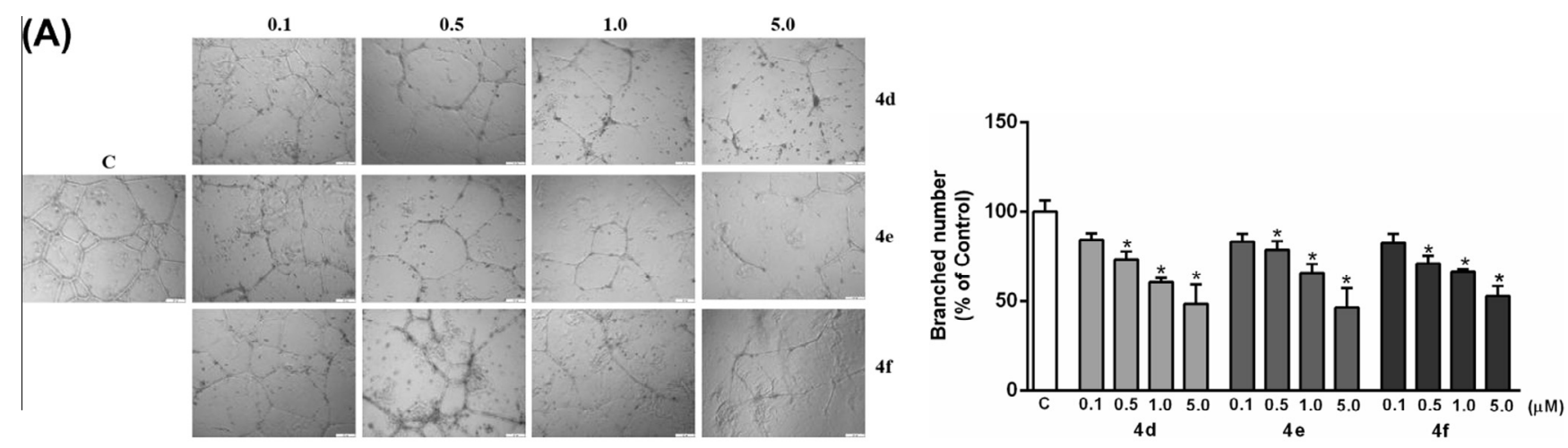

(B)
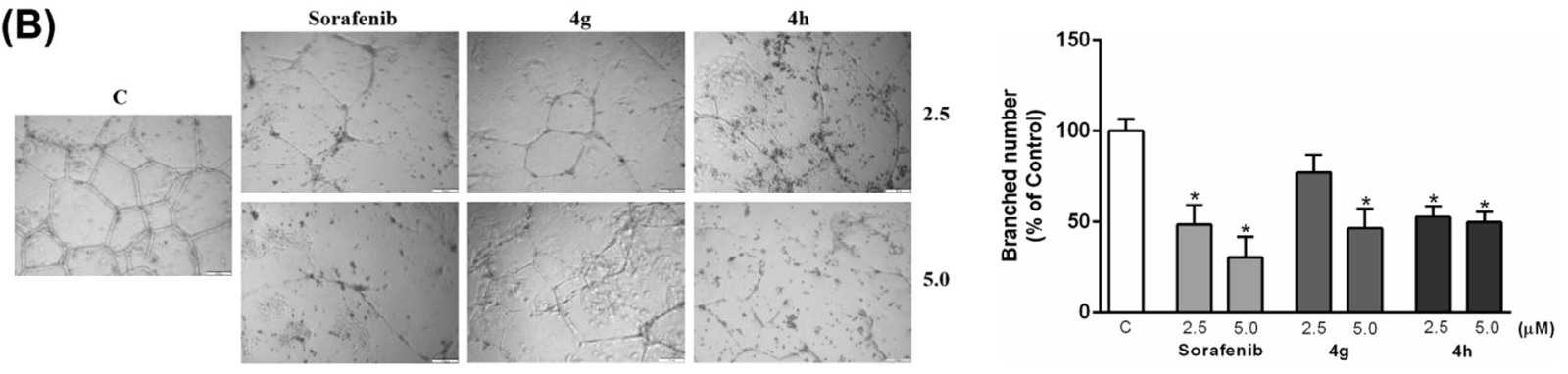

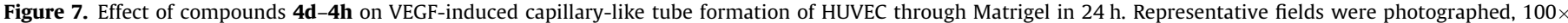

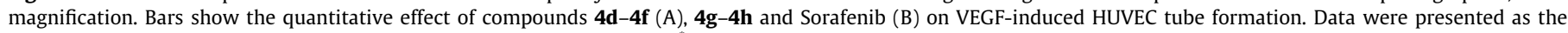
percentage of control, as mean \pm SEM of three independent experiments. ${ }^{*} p<0.001$ versus control. 
(A)

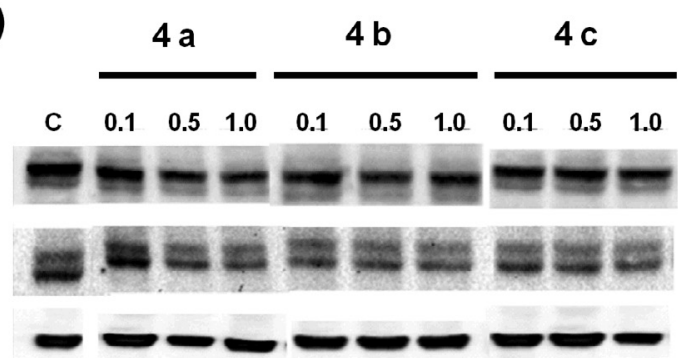

(B)

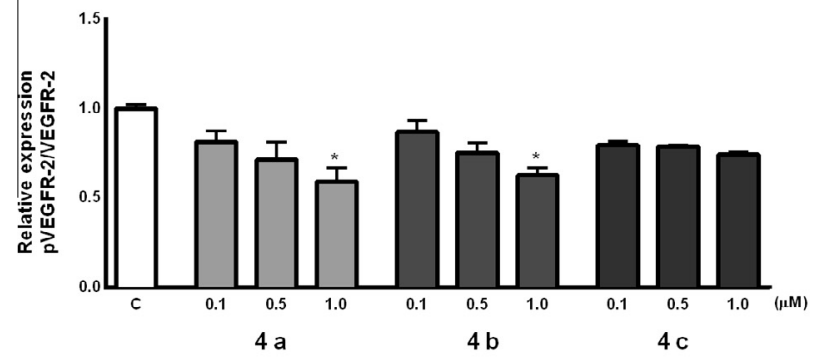

(E)

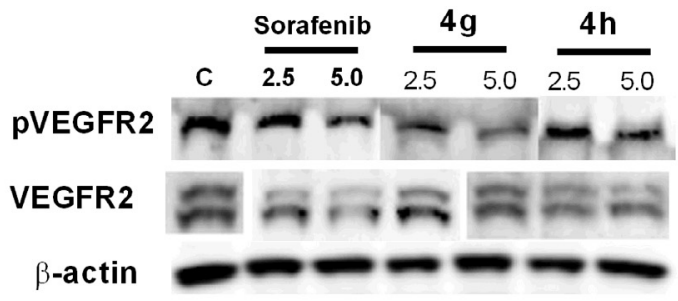

(C) $4 d$ $\frac{4 \mathrm{e}}{0.1 \quad 0.5 \quad 1.0} \frac{4 \mathrm{f}}{0.1 \quad 0.5 \quad 1.0}$

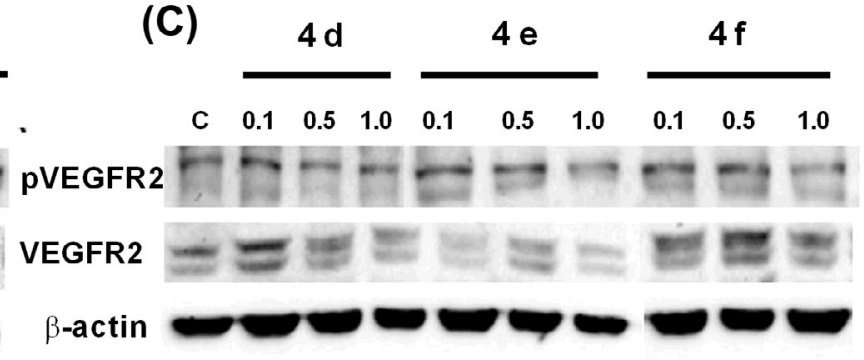

\section{PVEGFR2}

VEGFR2

$\beta$-actin

(D)

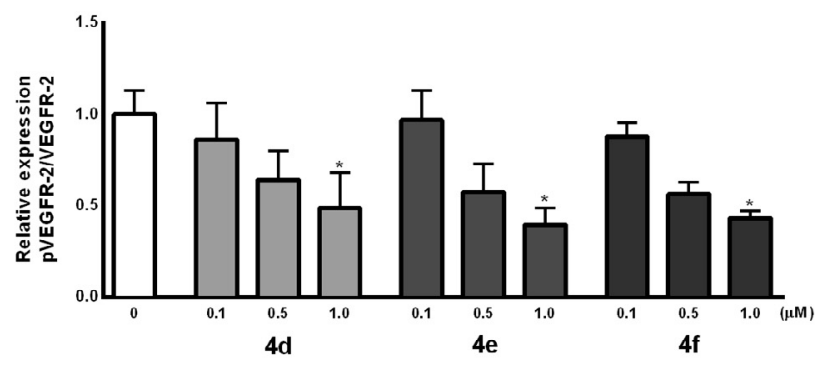

(F)

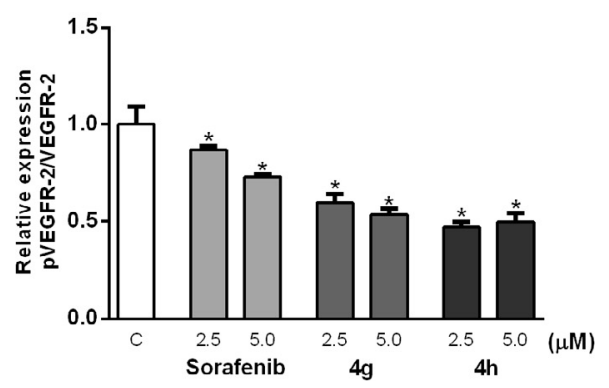

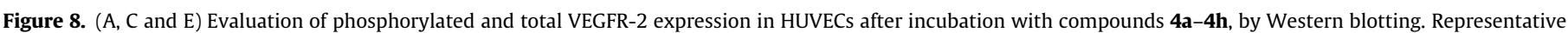

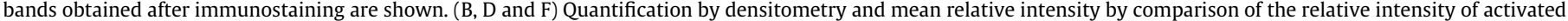
VEGFR-2 after normalization with total VEGFR-2 intensity. Data presented as mean \pm SEM of two independent experiments. ${ }^{*} p<0.05$ versus control.

\section{Experimental section}

\subsection{Synthesis}

Melting points $\left({ }^{\circ} \mathrm{C}\right)$ were determined in a Stuart SMP3 and are uncorrected. ${ }^{1} \mathrm{H}$ and ${ }^{13} \mathrm{C}$ NMR spectra were recorded on a Varian Unity Plus at 300 and $75.4 \mathrm{MHz}$, respectively or on a Bruker Avance III at 400 and $100.6 \mathrm{MHz}$, respectively, and the chemical shifts were quoted in parts per million ( $\mathrm{ppm}$ ) referenced to the appropriate non-deuterated solvent peak relative to $0.0 \mathrm{ppm}$ for tetramethylsilane. Two dimensional ${ }^{1} \mathrm{H}-{ }^{13} \mathrm{C}$ correlations were performed to attribute some signals. Mass spectra (MS) EI-TOF or ESI-TOF and HRMS on the $\mathrm{M}^{+}$or on the $[\mathrm{M}+\mathrm{H}]^{+}$were performed by the mass spectrometry service of the University of Vigo, C.A.C.T.I., Spain and the low resolution MS ESI of compounds $4 \mathrm{~g}, 4 \mathbf{h}, \mathbf{5 d}$ and $5 \mathbf{e}$ were performed by direct injection on a ThermoFinigan spectrophotometer LC-MS. Elemental Analysis was performed on a LECO CHNS 932 Elemental Analyser. The compounds yielded data consistent with a purity of at least $95 \%$ as compared with the theoretical values. The reactions were monitored by thin layer chromatography (TLC) using Macherey-Nagel pre-coated aluminium silica gel 60 sheets $(0.20 \mathrm{~mm})$ with UV254 indicator. Column chromatography was performed on Panreac, Silica Gel 60, 230-400 mesh. Ether refers to diethylether. Petroleum ether refers to the boiling range $40-60^{\circ} \mathrm{C}$. Aminothiophenols were purchased from Sigma-Aldrich with purity $\geqslant 96 \%$.

\subsubsection{General synthesis procedure for compounds $2 a-c$}

In a flask with DMF ( $5 \mathrm{~mL})$, compound $\mathbf{1}$, the aminothiophenol (1 equiv) and $\mathrm{K}_{2} \mathrm{CO}_{3}$ (4 equiv) were heated at $140{ }^{\circ} \mathrm{C}$ for $2 \mathrm{~h}$. After cooling water $(5 \mathrm{~mL})$ and ethyl acetate $(5 \mathrm{~mL})$ were added. The phases were separated and the aqueous phase was extracted with more ethyl acetate $(2 \times 5 \mathrm{~mL})$. The organic phase was dried $\left(\mathrm{MgSO}_{4}\right)$ and filtered. The solvent was evaporated under reduced pressure giving an oil which was submitted to column chromatography.

4.1.1.1. 2-(Thieno[3,2-b]pyridin-7-ylthio)aniline (2a). Compound 1 (150 $\mathrm{mg}, 0.880 \mathrm{mmol}$ ) and 2-aminothiophenol $(110 \mathrm{mg})$ and the general procedure was followed. Column chromatography using $70 \%$ ether/petroleum ether gave compound 2a as an oil $(180 \mathrm{mg}$, 80\%). ${ }^{1} \mathrm{H}$ NMR (DMSO- $d_{6}, 300 \mathrm{MHz}$ ): $\delta 5.54$ (br s, $\left.2 \mathrm{H}, \mathrm{NH}_{2}\right), 6.57$ $\left(\mathrm{d}, J=5.2 \mathrm{~Hz}, 1 \mathrm{H}, 6^{\prime}-\mathrm{H}\right), 6.62-6.67(\mathrm{~m}, 1 \mathrm{H}, 4-\mathrm{H}), 6.87(\mathrm{dd}, J=8.4$ and $1.5 \mathrm{~Hz}, 1 \mathrm{H}, 6-\mathrm{H}), 7.25-7.30(\mathrm{~m}, 1 \mathrm{H}, 5-\mathrm{H}), 7.37(\mathrm{dd}, J=8.4$ and $1.5 \mathrm{~Hz}, 1 \mathrm{H}, 3-\mathrm{H}), 7.57$ (d, $J=5.6 \mathrm{~Hz}, 1 \mathrm{H}$, HetArH), 8.14 (d, $J=5.6 \mathrm{~Hz}, 1 \mathrm{H}$, HetArH), $8.42\left(\mathrm{~d}, J=5.2 \mathrm{~Hz}, 1 \mathrm{H}, 5^{\prime}-\mathrm{H}\right) \mathrm{ppm} .{ }^{13} \mathrm{C}$ NMR (DMSO- $d_{6}, 75.4 \mathrm{MHz}$ ): $\delta 107.2$ (C), $114.0\left(6^{\prime}-\mathrm{CH}\right), 115.3$ (6-CH), $116.9(4-\mathrm{CH}), 124.9(\mathrm{CH}), 129.3(\mathrm{C}), 131.6(\mathrm{CH}), 132.3$ 
(5-CH), 137.4 (3-CH), 142.5 (C), 147.2 (5'-CH), 151.1 (C), 155.7 (C) ppm. MS (EI- TOF) $\mathrm{m} / z(\%): 258.03\left(\mathrm{M}^{+}, 100\right)$. HRMS (EI-TOF): calcd for $\mathrm{C}_{13} \mathrm{H}_{10} \mathrm{~N}_{2} \mathrm{~S}_{2}\left[\mathrm{M}^{+}\right] 258.0285$, found 258.0284.

4.1.1.2. 3-(Thieno[3,2-b]pyridin-7-ylthio)aniline (2b). Compound 1 (200 $\mathrm{mg}, 1.20 \mathrm{mmol}$ ) and 3-aminothiophenol (125 mg) and the general procedure was followed. Column chromatography using $45 \%$ ether/petroleum ether gave compound $\mathbf{2 b}$ as a yellow solid (280 mg, 90\%). Mp 106-107 ${ }^{\circ} \mathrm{C} .{ }^{1} \mathrm{H}$ NMR (DMSO- $\left.d_{6}, 400 \mathrm{MHz}\right): \delta$ 5.40 (br s, 2H, $\left.\mathrm{NH}_{2}\right), 6.69-6.71(\mathrm{~m}, 2 \mathrm{H}, 4$ and 6-H), 6.75-6.76 (m, $1 \mathrm{H}, 2-\mathrm{H}$ ), 6.87 (d, $J=4.8 \mathrm{~Hz}, 1 \mathrm{H}, 6^{\prime}-\mathrm{H}$ ), 7.14 (apparent t, $J=8 \mathrm{~Hz}$, $1 \mathrm{H}, 5-\mathrm{H}), 7.58$ (d, $J=5.6 \mathrm{~Hz}, 1 \mathrm{H}$, HetArH), $8.14(\mathrm{~d}, J=5.6 \mathrm{~Hz}, 1 \mathrm{H}$, HetArH), 8.49 (d, $J=4.8 \mathrm{~Hz}, 1 \mathrm{H}, 5^{\prime}-\mathrm{H}$ ) ppm. ${ }^{13} \mathrm{C}$ MNR (DMSO- $d_{6}$, $100.6 \mathrm{MHz}): \delta 115.2(\mathrm{CH}), 116.0\left(6^{\prime}-\mathrm{CH}\right), 118.7(2-\mathrm{CH}), 121.0$ $(\mathrm{CH}), 125.0(\mathrm{CH}), 128.1(\mathrm{C}), 130.3(\mathrm{C}), 130.5(5-\mathrm{CH}), 131.8(\mathrm{CH})$, 142.8 (C), 147.4 (5'-CH), 150.3 (C), 155.7 (C) ppm. MS (ESI- TOF) $m / z \quad \%): 259.03 \quad\left(\mathrm{M}^{+}+\mathrm{H}, 100\right)$. HRMS (ESI-TOF): calcd for $\mathrm{C}_{13} \mathrm{H}_{11} \mathrm{~N}_{2} \mathrm{~S}_{2}\left[\mathrm{M}^{+}+\mathrm{H}\right] 259.0358$, found 259.0358. Anal. Calcd for $\mathrm{C}_{13} \mathrm{H}_{10} \mathrm{~N}_{2} \mathrm{~S}_{2}$ : C, 60.43; H, 3.90; N, 10.84; S, 24.82. Found: C, 60.57; $\mathrm{H}, 4.01$; N, 11.02; S, 24.42.

4.1.1.3. 4-(Thieno[3,2-b]pyridin-7-ylthio)aniline (2c). Compound $1(150 \mathrm{mg}, 0.880 \mathrm{mmol}$ ) and 4-aminothiophenol $(110 \mathrm{mg})$ was treated according to the general procedure. Column chromatography using $40 \%$ ether/petroleum ether gave compound $2 \mathrm{c}$ as a yellow solid (210 mg, 90\%). Mp 215-216 ${ }^{\circ} \mathrm{C} .{ }^{1} \mathrm{H} \mathrm{NMR}\left(\mathrm{CDCl}_{3}\right.$, $400 \mathrm{MHz}$ ): $\delta 3.85$ (br s, $\left.2 \mathrm{H}, \mathrm{NH}_{2}\right), 6.70\left(\mathrm{~d}, J=5.2 \mathrm{~Hz}, 1 \mathrm{H}, 6^{\prime}-\mathrm{H}\right)$, $6.76(\mathrm{~d}, J=8.4 \mathrm{~Hz}, 2 \mathrm{H}, 2$ and $6-\mathrm{H}), 7.40(\mathrm{~d}, J=8.4 \mathrm{~Hz}, 2 \mathrm{H}, 3$ and $5-$ H), $7.64(\mathrm{~d}, J=5.6 \mathrm{~Hz}, 1 \mathrm{H}$, HetArH), 7.78 (d, $J=5.6 \mathrm{~Hz}, 1 \mathrm{H}, \mathrm{HetArH})$, $8.39\left(\mathrm{~d}, J=5.2 \mathrm{~Hz}, 1 \mathrm{H}, 5^{\prime}-\mathrm{H}\right) \mathrm{ppm} .{ }^{13} \mathrm{C} \mathrm{NMR}\left(\mathrm{CDCl}_{3}, 100.6 \mathrm{MHz}\right): \delta$ $114.5\left(6^{\prime}-\mathrm{CH}\right), 116.0$ (2 and 6-CH), $124.2(\mathrm{CH}), 130.2(\mathrm{C}), 131.1$ $(\mathrm{CH}), 135.8$ (C), 136.4 (C), 137.4 (3 and 5-CH), $145.2\left(5^{\prime}-\mathrm{CH}\right)$, 148.7 (C), 153.6 (C) ppm. MS (EI- TOF) $m / z$ (\%): $258.03\left(\mathrm{M}^{+}, 100\right)$. HRMS (EI-TOF): calcd for $\mathrm{C}_{13} \mathrm{H}_{10} \mathrm{~N}_{2} \mathrm{~S}_{2}\left[\mathrm{M}^{+}\right]$258.0285, found 258.0289. Anal. Calcd for $\mathrm{C}_{13} \mathrm{H}_{10} \mathrm{~N}_{2} \mathrm{~S}_{2}$ : C, 60.43; H, 3.90; N, 10.84; S, 24.82. Found: C, 60.59; H, 4.11; N, 10.90; S, 24.40.

\subsubsection{General procedure for the synthesis of 1,3-diarylureas 3-5}

Compounds 2a-c and different arylisocyanates (1 equiv) in $6 \mathrm{~mL} \mathrm{CH}_{2} \mathrm{Cl}_{2}$ /THF (1:1) were left stirring at room temperature for $12 \mathrm{~h}$. If a precipitate does not come out after this time, hexane (3-5 $\mathrm{mL}$ ) was added to the mixture to precipitate the product. This was filtered under vacuum to give the corresponding 1,3diarylureas.

4.1.2.1. 1-Phenyl-3-[2-(thieno[3,2-b]pyridin-7-ylthio)phenyl]urea (3a). From compound 2a $(100 \mathrm{mg}, 0.390 \mathrm{mmol})$ and phenylisocyanate $(50.0 \mathrm{mg}$ ) compound 3a was isolated as a green solid (95.0 mg, 65\%). Mp 198-199 ${ }^{\circ} \mathrm{C}$. ${ }^{1} \mathrm{H}$ NMR (DMSO- $d_{6}$, $300 \mathrm{MHz}): \delta 6.56(\mathrm{~d}, 1 \mathrm{H}, J=4.8 \mathrm{~Hz}), 6.92-6.98(\mathrm{~m}, 1 \mathrm{H}), 7.12-7.18$ $(\mathrm{m}, 1 \mathrm{H}), 7.24-7.29(\mathrm{~m}, 2 \mathrm{H}), 7.37-7.46(\mathrm{~m}, 2 \mathrm{H}), 7.54-7.63(\mathrm{~m}$, $3 \mathrm{H}), 8.18(\mathrm{~d}, 1 \mathrm{H}, J=5.6 \mathrm{~Hz}), 8.28-8.31(\mathrm{~m}, 1 \mathrm{H}), 8.45(\mathrm{~d}, 1 \mathrm{H}$, $J=4.8 \mathrm{~Hz}$ ), 8.49 (br s, $1 \mathrm{H}, \mathrm{NH}), 9.36$ (br s, $1 \mathrm{H}, \mathrm{NH}) \mathrm{ppm} .{ }^{13} \mathrm{C} \mathrm{NMR}$ (DMSO- $d_{6}, 75.4 \mathrm{MHz}$ ): $\delta 114.3(\mathrm{CH}), 115.3(\mathrm{C}), 118.2(\mathrm{CH}), 118.3$ $(2 \times \mathrm{CH}), 121.3(\mathrm{CH}), 122.1(\mathrm{CH}), 123.6(\mathrm{CH}), 125.0(\mathrm{CH}), 128.8$ $(2 \times \mathrm{CH}), 129.5(\mathrm{C}), 131.9(\mathrm{CH}), 137.3(\mathrm{CH}), 139.3(\mathrm{C}), 142.3(\mathrm{C})$, 142.4 (C), $147.5(\mathrm{CH}), 152.2$ (C), 155.8 (C) ppm. MS (ESI-TOF) $\mathrm{m} / \mathrm{z}$ (\%): $378.07\left(\mathrm{M}^{+}+\mathrm{H}, 100\right)$ HRMS (ESI-TOF): calcd for $\mathrm{C}_{20} \mathrm{H}_{16} \mathrm{~N}_{3} \mathrm{OS}_{2}$ $\left[\mathrm{M}^{+}+\mathrm{H}\right]$ 378.0729, found 378.0723. Anal. Calcd for $\mathrm{C}_{20} \mathrm{H}_{15} \mathrm{~N}_{3} \mathrm{OS}_{2}$ : C, 63.64; H, 4.01; N, 11.13; S, 16.99. Found: C, 63.83; H, 4.13; N, $10.83 ; \mathrm{S}, 16.60$.

4.1.2.2. 1-(4-Methoxyphenyl)-3-[2-(thieno[3,2-b]pyridin-7-ylthio)phenyl]urea (3b). From compound 2a (100 mg, $0.390 \mathrm{mmol})$ and 4-methoxyphenylisocyanate $(83.0 \mathrm{mg})$, compound $\mathbf{3 b}$ was isolated as a green solid (100 mg, 63\%). Mp 198-199 ${ }^{\circ} \mathrm{C} .{ }^{1} \mathrm{H}$ NMR (DMSO- $\left.d_{6}, 400 \mathrm{MHz}\right): \delta 3.68$ (s, 3H, OMe), 6.55 (d, $\left.J=5.2 \mathrm{~Hz}, 1 \mathrm{H}\right)$, $6.82(\mathrm{~d}, J=9.2 \mathrm{~Hz}, 2 \mathrm{H}), 7.13(\mathrm{~m}, 1 \mathrm{H}), 7.28(\mathrm{~d}, J=9.2 \mathrm{~Hz}, 2 \mathrm{H})$, $7.53-7.61(\mathrm{~m}, 3 \mathrm{H}), 8.18(\mathrm{~d}, J=5.6 \mathrm{~Hz}, 1 \mathrm{H}), 8.31$ (dd, $J=8.4$ and $1.2 \mathrm{~Hz}, 1 \mathrm{H}), 8.38$ (br s, 1H, NH), 8.45 (d, $J=5.2 \mathrm{~Hz}, 1 \mathrm{H}), 9.17$ (br s, $1 \mathrm{H}, \mathrm{NH}) \mathrm{ppm} .{ }^{13} \mathrm{C}$ NMR (DMSO- $\left.d_{6}, 100.6 \mathrm{MHz}\right): \delta 55.1$ (OMe), $114.0(2 \times \mathrm{CH}), 114.2(\mathrm{CH}), 114.9(\mathrm{C}), 120.1(2 \times \mathrm{CH}), 121.0(\mathrm{CH})$, $123.3(\mathrm{CH}), 125.0(\mathrm{CH}), 129.4(\mathrm{C}), 131.8(\mathrm{CH}), 131.9(\mathrm{CH}), 132.2$ (C), $137.2(\mathrm{CH}), 142.3(\mathrm{C}), 142.5(\mathrm{C}), 147.5(\mathrm{CH}), 152.3(\mathrm{C}), 154.6$ (C), 155.8 (C) ppm. MS (ESI-TOF) $m / z$ (\%): $408.08\left(\mathrm{M}^{+}+\mathrm{H}, 100\right)$. HRMS (ESI-TOF): calcd for $\mathrm{C}_{21} \mathrm{H}_{18} \mathrm{~N}_{3} \mathrm{O}_{2} \mathrm{~S}_{2}\left[\mathrm{M}^{+}+\mathrm{H}\right] 408.0835$, found 408.0832. Anal. Calcd for $\mathrm{C}_{21} \mathrm{H}_{17} \mathrm{~N}_{3} \mathrm{O}_{2} \mathrm{~S}_{2}$ : C, 61.89; $\mathrm{H}, 4.20 ; \mathrm{N}$, 10.31; S, 15.74. Found: C, 62.01; H, 4.05; N, 11.00; S, 15.33 .

4.1.2.3. 1-(4-Cyanophenyl)-3-[2-(thieno[3,2-b]piridin-7-ylthio)phenyl]urea (3c). From compound 2a $(60.0 \mathrm{mg}, 0.230 \mathrm{mmol})$ and 4-cyanophenylisocyanate $(37.0 \mathrm{mg})$ compound $3 \mathrm{c}$ was isolated as a green solid (60.0 mg, 65\%). Mp 208-209 ${ }^{\circ} \mathrm{C} .{ }^{1} \mathrm{H}$ NMR (DMSO- $\left.d_{6}, 300 \mathrm{MHz}\right): \delta 6.57(\mathrm{~d}, J=5.2 \mathrm{~Hz}, 1 \mathrm{H}), 7.17-7.22(\mathrm{~m}$, $1 \mathrm{H}), 7.58-7.60(\mathrm{~m}, 5 \mathrm{H}), 7.68(\mathrm{~d}, J=9.2 \mathrm{~Hz}, 2 \mathrm{H}), 8.17(\mathrm{~d}, J=5.6 \mathrm{~Hz}$, $1 \mathrm{H}), 8.24(\mathrm{dd}, J=8.4$ and $1.5 \mathrm{~Hz}, 1 \mathrm{H}), 8.45(\mathrm{~d}, J=5.2 \mathrm{~Hz}, 1 \mathrm{H}), 8.65$ (br s, $1 \mathrm{H}, \mathrm{NH}), 9.80$ (br s, $1 \mathrm{H}, \mathrm{NH}) \mathrm{ppm} .{ }^{13} \mathrm{C}$ NMR (DMSO-d $d_{6}$, $75.4 \mathrm{MHz})$ : $\delta 103.6(\mathrm{C}), 114.5(\mathrm{CH}), 116.3(\mathrm{C}), 118.1(2 \times \mathrm{CH})$, $119.2(\mathrm{C}), 121.7(\mathrm{CH}), 124.3(\mathrm{CH}), 125.0(\mathrm{CH}), 129.6(\mathrm{C}), 131.9$ (CH), $131.9(\mathrm{CH}), 133.3(2 \times \mathrm{CH}), 137.2(\mathrm{CH}), 141.7(\mathrm{C}), 142.1(\mathrm{C})$, 143.8 (C), 147.5 (CH), 151.9 (C), 155.8 (C) ppm. MS (ESI-TOF) m/z (\%): $403.07\left(\mathrm{M}^{+}+\mathrm{H}, 100\right)$. HRMS (ESI-TOF): calcd for $\mathrm{C}_{21} \mathrm{H}_{15} \mathrm{~N}_{4} \mathrm{OS}_{2}$ $\left[\mathrm{M}^{+}+\mathrm{H}\right]$ 403.0682, found 403.0689. Anal. Calcd for $\mathrm{C}_{21} \mathrm{H}_{14} \mathrm{~N}_{4} \mathrm{OS}_{2}$ : C, 62.67; H, 3.51; N, 13.92; S, 15.93. Found: C, 62.95; H, 3.32; N, 14.12; S, 15.51 .

4.1.2.4. 1-Phenyl-3-[3-(thieno[3,2-b]pyridin-7-ylthio)phenyl]urea (4a). From compound $\mathbf{2 b}(80.0 \mathrm{mg}, 0.300 \mathrm{mmol})$ and phenylisocyanate $(36.0 \mathrm{mg}$ ) compound 4 a was isolated as a yellow solid (70 mg, 63\%). Mp 94-95 ${ }^{\circ} \mathrm{C} .{ }^{1} \mathrm{H}$ NMR (DMSO- $\left.d_{6}, 400 \mathrm{MHz}\right): \delta$ $6.95(\mathrm{~d}, J=5.2 \mathrm{~Hz}, 1 \mathrm{H}), 6.96-6.98(\mathrm{~m}, 1 \mathrm{H}), 7.17-7.20(\mathrm{~m}, 1 \mathrm{H})$, 7.24-7.28 (m, 2H), 7.39-7.44 (m, 3H), 7.49-7.52 (m, 1H), $7.60(\mathrm{~d}$, $J=5.6 \mathrm{~Hz}, 1 \mathrm{H}), 7.78-7.79(\mathrm{~m}, 1 \mathrm{H}), 8.16(\mathrm{~d}, J=5.6 \mathrm{~Hz}, 1 \mathrm{H}), 8.52(\mathrm{~d}$, $J=5.2 \mathrm{~Hz}, 1 \mathrm{H}), 8.70$ (br s, $1 \mathrm{H}, \mathrm{NH}), 8.90$ (br s, $1 \mathrm{H}, \mathrm{NH}) \mathrm{ppm} .{ }^{13} \mathrm{C}$ NMR (DMSO-d $\left.d_{6}, 100.6 \mathrm{MHz}\right): \delta 116.5(\mathrm{CH}), 118.4(2 \times \mathrm{CH}), 119.3$ (CH), $122.1(\mathrm{CH}), 122.8(\mathrm{CH}), 125.0(\mathrm{CH}), 127.0(\mathrm{CH}), 128.7$ $(2 \times \mathrm{CH}), 128.8(\mathrm{C}), 130.5(\mathrm{CH}), 130.8(\mathrm{C}), 132.0(\mathrm{CH}), 139.4(\mathrm{C})$, $141.2(\mathrm{C}), 141.9(\mathrm{C}), 147.6(\mathrm{CH}), 152.4(\mathrm{C}), 155.9$ (C) ppm. MS (ESI-TOF) $m / z$ (\%): $378.07\left(\mathrm{M}^{+}+\mathrm{H}, 100\right)$ HRMS (ESI-TOF): calcd for $\mathrm{C}_{20} \mathrm{H}_{16} \mathrm{~N}_{3} \mathrm{OS}_{2}\left[\mathrm{M}^{+}+\mathrm{H}\right]$ 378.0729, found 378.0728. Anal. Calcd for $\mathrm{C}_{20} \mathrm{H}_{15} \mathrm{~N}_{3} \mathrm{OS}_{2}$ : C, 63.64; H, 4.01; N, 11.13; S, 16.99. Found: C, 63.86; H, 3.80; N, 11.33; S, 16.59 .

4.1.2.5. 1-(4-Methoxyphenyl)-3-[3-(thieno[3,2-b]pyridin-7-ylthio)phenyl]urea (4b). From compound $\mathbf{2 b}$ (100 $\mathrm{mg}, 0.390 \mathrm{mmol})$ and 4-methoxyphenylisocyanate $(58.0 \mathrm{mg}$ ), compound $\mathbf{4 b}$ was isolated as a yellow solid (100 mg, 64\%). Mp $132-133{ }^{\circ} \mathrm{C} .{ }^{1} \mathrm{H}$ NMR (DMSO- $\left.d_{6}, 400 \mathrm{MHz}\right): \delta 3.69$ (s, 3H, OMe), $6.84(\mathrm{~d}, J=8.8 \mathrm{~Hz}, 2 \mathrm{H})$, $6.92(\mathrm{~d}, J=4.8 \mathrm{~Hz}, 1 \mathrm{H}), 7.16-7.18(\mathrm{~m}, 1 \mathrm{H}), 7.31(\mathrm{~d}, J=8.8 \mathrm{~Hz}, 2 \mathrm{H})$, $7.30-7.33(\mathrm{~m}, 1 \mathrm{H}), 7.48-7.51(\mathrm{~m}, 1 \mathrm{H}), 7.60(\mathrm{~d}, J=5.6 \mathrm{~Hz}, 1 \mathrm{H})$, 7.77-7.78 (m, 1H), $8.16(\mathrm{~d}, J=5.6 \mathrm{~Hz}, 1 \mathrm{H}), 8.50$ (br s, $1 \mathrm{H}, \mathrm{NH})$, $8.52(\mathrm{~d}, J=4.8 \mathrm{~Hz}, 1 \mathrm{H}), 8.80$ (br s, $1 \mathrm{H}, \mathrm{NH}) \mathrm{ppm} .{ }^{13} \mathrm{C}$ NMR (DMSO$\left.d_{6}, 100.6 \mathrm{MHz}\right): \delta 55.1(\mathrm{OMe}), 113.9(2 \times \mathrm{CH}), 116.5(\mathrm{CH}), 119.2$ (CH), $120.3(2 \times \mathrm{CH}), 122.7(\mathrm{CH}), 125.0(\mathrm{CH}), 126.9(\mathrm{CH}), 128.8$ (C), $130.4(\mathrm{CH}), 130.7(\mathrm{C}), 132.0(\mathrm{CH}), 132.3(\mathrm{C}), 141.4(\mathrm{C}), 141.9$ (C), $147.6(\mathrm{CH}), 152.6(\mathrm{C}), 154.6(\mathrm{C}), 155.9$ (C) ppm. MS (ESI-TOF) $m / z$ (\%): $408.08\left(\mathrm{M}^{+}+\mathrm{H}, 100\right)$. HRMS (ESI-TOF): calcd for $\mathrm{C}_{21} \mathrm{H}_{18} \mathrm{~N}_{3^{-}}$ $\mathrm{O}_{2} \mathrm{~S}_{2}\left[\mathrm{M}^{+}+\mathrm{H}\right]$ 408.0835, found 408.0833. Anal. Calcd for $\mathrm{C}_{21} \mathrm{H}_{17} \mathrm{~N}_{3^{-}}$ $\mathrm{O}_{2} \mathrm{~S}_{2}$ : C, 61.89; H, 4.20; N, 10.31; S, 15.74. Found: C, 62.20; H, 4.45; N, 10.02; S, 15.35 . 
4.1.2.6. 1-(4-Cyanophenyl)-3-[3-(thieno[3,2-b]pyridin-7-ylthio)phenyl]urea (4c). From compound $\mathbf{2 b}(60.0 \mathrm{mg}, 0.230 \mathrm{mmol})$ and 4-cyanophenylisocyanate $(35.0 \mathrm{mg})$, compound $4 \mathrm{c}$ was isolated as a yellow solid (65.0 mg, 65\%). Mp $168-169{ }^{\circ} \mathrm{C} .{ }^{1} \mathrm{H}$ NMR (DMSO- $\left.d_{6}, 400 \mathrm{MHz}\right): \delta 6.95(\mathrm{~d}, J=5.2 \mathrm{~Hz}, 1 \mathrm{H}), 7.21-7.24(\mathrm{~m}$, $1 \mathrm{H}), 7.42-7.46(\mathrm{~m}, 1 \mathrm{H}), 7.52-7.55(\mathrm{~m}, 1 \mathrm{H}), 7.59(\mathrm{~d}, J=5.6 \mathrm{~Hz}$, $1 \mathrm{H}), 7.60(\mathrm{~d}, J=8.8 \mathrm{~Hz}, 2 \mathrm{H}), 7.71(\mathrm{~d}, J=8.8 \mathrm{~Hz}, 2 \mathrm{H}), 7.76-7.77(\mathrm{~m}$, $1 \mathrm{H}), 8.16(\mathrm{~d}, J=5.6 \mathrm{~Hz}, 1 \mathrm{H}), 8.53(\mathrm{~d}, J=5.2 \mathrm{~Hz}, 1 \mathrm{H}), 9.07$ (br s, $1 \mathrm{H}$, $\mathrm{NH}), 9.23$ (br s, $1 \mathrm{H}, \mathrm{NH})$ ppm. ${ }^{13} \mathrm{C}$ NMR (DMSO-d, $\left.100.6 \mathrm{MHz}\right): \delta$ $103.5(\mathrm{C}), 116.7(\mathrm{CH}), 118.2(2 \times \mathrm{CH}), 119.2(\mathrm{C}), 119.6(\mathrm{CH}), 123.0$ $(\mathrm{CH}), 125.0(\mathrm{CH}), 127.5(\mathrm{CH}), 129.0(\mathrm{C}), 130.5(\mathrm{CH}), 130.9(\mathrm{C})$, $132.0(\mathrm{CH}), 133.2(2 \times \mathrm{CH}), 140.7(\mathrm{C}), 141.6(\mathrm{C}), 143.9(\mathrm{C}), 147.6$ (CH), 152.0 (C), 155.9 (C) ppm. MS (ESI- TOF) $\mathrm{m} / \mathrm{z}$ (\%): 403.07 $\left(\mathrm{M}^{+}+\mathrm{H}, 100\right)$ HRMS (ESI-TOF): calcd for $\mathrm{C}_{21} \mathrm{H}_{15} \mathrm{~N}_{4} \mathrm{OS}_{2}\left[\mathrm{M}^{+}+\mathrm{H}\right]$ 403.0682, found 403.0680. Anal. Calcd for $\mathrm{C}_{21} \mathrm{H}_{14} \mathrm{~N}_{4} \mathrm{OS}_{2}$ : C, 62.67; H, 3.51; N, 13.92; S, 15.93. Found: C, 62.37; H, 3.80; N, 14.13; S, 15.52.

4.1.2.7. 1-(4-Fluorophenyl)-3-[3-(thieno[3,2-b]pyridin-7-ylthio]phenyl)urea (4d). From compound $\mathbf{2 b}(60.0 \mathrm{mg}, 0.230 \mathrm{mmol})$ and 4-fluorophenylisocyanate $(35.0 \mathrm{mg})$, compound $\mathbf{4 d}$ was isolated as a white solid (65.0 mg, 71\%). Mp $140-141{ }^{\circ} \mathrm{C} .{ }^{1} \mathrm{H}$ NMR $\left(\right.$ DMSO $\left.-d_{6}, 400 \mathrm{MHz}\right): \delta 6.93(1 \mathrm{H}, \mathrm{d}, J=5.2 \mathrm{~Hz}), 7.07-7.12(\mathrm{~m}$, $2 \mathrm{H}), 7.18-7.20(\mathrm{~m}, 1 \mathrm{H}), 7.39-7.44(\mathrm{~m}, 3 \mathrm{H}), 7.50-7.52(\mathrm{~m}, 1 \mathrm{H})$, $7.60(\mathrm{~d}, J=5.6 \mathrm{~Hz}, 1 \mathrm{H}), 7.76-7.77(\mathrm{~m}, 1 \mathrm{H}), 8.16(\mathrm{~d}, J=5.6 \mathrm{~Hz}, 1 \mathrm{H})$, 8.52 (d, $J=5.2 \mathrm{~Hz}, 1 \mathrm{H}), 8.73$ (br s, $1 \mathrm{H}, \mathrm{NH}), 8.89$ (br s, 1H, NH) ppm. ${ }^{13} \mathrm{C}$ NMR (DMSO-d, $\left.100.6 \mathrm{MHz}\right): \delta 115.3(\mathrm{~d}, J=22 \mathrm{~Hz}$, $2 \times \mathrm{CH}), 116.6(\mathrm{CH}), 119.4(\mathrm{CH}), 120.2(\mathrm{~d}, J=7.0 \mathrm{~Hz}, 2 \times \mathrm{CH})$, $122.8(\mathrm{CH}), 125.1(\mathrm{CH}), 127.1(\mathrm{CH}), 128.9(\mathrm{C}), 130.5(\mathrm{CH}), 130.8$ (C), $132.0(\mathrm{CH}), 135.7(\mathrm{C}), 141.2(\mathrm{C}), 141.9(\mathrm{C}), 147.6(\mathrm{CH}), 152.5$ (C), 155.9 (C), 157.5 (d, $J=238 \mathrm{~Hz}, \mathrm{CF}$ ) ppm. MS (ESI-TOF) $\mathrm{m} / z$ (\%): $396.06\left(\mathrm{M}^{+}+\mathrm{H}, 100\right)$. HRMS (ESI-TOF): calcd for $\mathrm{C}_{20} \mathrm{H}_{15} \mathrm{FN}_{3} \mathrm{OS}_{2}$ $\left[\mathrm{M}^{+}+\mathrm{H}\right] 396.0635$, found 396.0634. Anal. Calcd for $\mathrm{C}_{20} \mathrm{H}_{14} \mathrm{FN}_{3} \mathrm{OS}_{2}$ : C, 60.74; H, 3.57; N, 10.63; S, 16.22. Found: C, 61.01; H, 3.28; N, $10.35 ; \mathrm{S}, 15.81$.

4.1.2.8. 1-(3-Fluorophenyl)-3-[3-(thieno[3,2-b]pyridin-7-ylthio)phenyl]urea (4e). From compound $\mathbf{2 b}(60.0 \mathrm{mg}, 0.230 \mathrm{mmol})$ and 3-fluorophenylisocyanate $(35.0 \mathrm{mg}$ ) compound $\mathbf{4 e}$ was isolated as a white solid (63.0 mg, 69\%). Mp 104-105 ${ }^{\circ} \mathrm{C} .{ }^{1} \mathrm{H}$ NMR (DMSO- $\left.d_{6}, 400 \mathrm{MHz}\right): \delta 6.77-6.78(\mathrm{~m}, 1 \mathrm{H}), 6.93(\mathrm{~d}, 1 \mathrm{H}$, $J=5.2 \mathrm{~Hz}), 7.09-7.11(\mathrm{~m}, 2 \mathrm{H}), 7.19-7.20(\mathrm{~m}, 1 \mathrm{H}), 7.21-7.29(\mathrm{~m}$, $1 \mathrm{H}), \quad 7.41-7.52(\mathrm{~m}, 2 \mathrm{H}), 7.53-7.54(\mathrm{~m}, 1 \mathrm{H}), 7.60(\mathrm{~d}, 1 \mathrm{H}$, $J=5.6 \mathrm{~Hz}), 7.7-7.7(\mathrm{~m}, 1 \mathrm{H}), 8.16(\mathrm{~d}, 1 \mathrm{H}, J=5.6 \mathrm{~Hz}), 8.52(\mathrm{~d}, 1 \mathrm{H}$, $J=5.2 \mathrm{~Hz}$ ), 8.94 (br s, $1 \mathrm{H}, \mathrm{NH}), 8.96$ (br s, $1 \mathrm{H}, \mathrm{NH}) \mathrm{ppm} .{ }^{13} \mathrm{C}$ NMR $\left(\right.$ DMSO$_{-} d_{6}, 100.6 \mathrm{MHz}$ ): $\delta 105.0$ (d, $\left.J=26 \mathrm{~Hz}, \mathrm{CH}\right), 108.4$ (d, $J=21 \mathrm{~Hz}, \mathrm{CH}), 114.1(\mathrm{~d}, J=2 \mathrm{~Hz}, \mathrm{CH}), 116.6(\mathrm{CH}), 119.5(\mathrm{CH})$, $122.9(\mathrm{CH}), 125.0(\mathrm{CH}), 127.3(\mathrm{CH}), 128.9(\mathrm{C}), 130.3$ (d, J = 9.6 Hz, $\mathrm{CH}), 130.5(\mathrm{CH}), 130.8$ (C), $132.0(\mathrm{CH}), 140.9$ (C), 141.3 (d, $J=11.5 \mathrm{~Hz}, \mathrm{C}), 141.8$ (C), $147.6(\mathrm{CH}), 152.2$ (C), 155.9 (C), 162.3 (d, $J=240 \mathrm{~Hz}, \mathrm{CF}$ ) ppm. MS (ESI-TOF) $\mathrm{m} / \mathrm{z}(\%)$ : $396.06\left(\mathrm{M}^{+}+\mathrm{H}\right.$, 100). HRMS (ESI-TOF): calcd for $\mathrm{C}_{20} \mathrm{H}_{15} \mathrm{FN}_{3} \mathrm{OS}_{2}\left[\mathrm{M}^{+}+\mathrm{H}\right]$ 396.0635, found 396.0627. Anal. Calcd for $\mathrm{C}_{20} \mathrm{H}_{14} \mathrm{FN}_{3} \mathrm{OS}_{2}$ : C, 60.74; $\mathrm{H}, 3.57$; N, 10.63; S, 16.22. Found: C, 61.03; H, 3.33; N, 10.30; S, 15.82.

4.1.2.9. 1-[3-(Thieno[3,2-b]pyridin-7-ylthio)phenyl]-3-m-tolylurea (4f). From compound $2 \mathbf{b}(60.0 \mathrm{mg}, 0.230 \mathrm{mmol})$ and $m$-tolylisocyanate $(35.0 \mathrm{mg}$ ) compound $\mathbf{4 f}$ was isolated as a white solid (65.0 mg, 72\%). Mp 157-158 ${ }^{\circ} \mathrm{C} .{ }^{1} \mathrm{H}$ NMR (DMSO-d 6 , $400 \mathrm{MHz}): \delta 2.25\left(\mathrm{~s}, 3 \mathrm{H}, \mathrm{CH}_{3}\right), 6.77-6.79(\mathrm{~m}, 1 \mathrm{H}), 6.93(\mathrm{~d}, 1 \mathrm{H}$, $J=4.8 \mathrm{~Hz}), 7.11-7.20(\mathrm{~m}, 3 \mathrm{H}), 7.26-7.29(\mathrm{~m}, 1 \mathrm{H}), 7.39-7.44(\mathrm{~m}$, $1 \mathrm{H}), 7.49-7.51(\mathrm{~m}, 1 \mathrm{H}), 7.60(\mathrm{~d}, 1 \mathrm{H}, J=5.6 \mathrm{~Hz}), 7.79-7.80(\mathrm{~m}$, $1 \mathrm{H}), 8.16(\mathrm{~d}, 1 \mathrm{H}, J=5.6 \mathrm{~Hz}), 8.52(\mathrm{~d}, 1 \mathrm{H}, J=4.8 \mathrm{~Hz}), 8.61(\mathrm{br} \mathrm{s}, 1 \mathrm{H}$, $\mathrm{NH}), 8.87$ (br s $1 \mathrm{H}, \mathrm{NH}) \mathrm{ppm} .{ }^{13} \mathrm{C}$ NMR (DMSO-d $\left.6,100.6 \mathrm{MHz}\right): \delta$ $21.2\left(\mathrm{CH}_{3}\right), 115.5(\mathrm{CH}), 116.5(\mathrm{CH}), 118.9(\mathrm{CH}), 119.3(\mathrm{CH}), 122.8$ $(\mathrm{CH}), 122.8(\mathrm{CH}), 125.0(\mathrm{CH}), 127.0(\mathrm{CH}), 128.6(\mathrm{CH}), 128.8(\mathrm{C})$,
$130.5(\mathrm{CH}), 132.0(\mathrm{CH}), 137.9(\mathrm{C}), 139.3(\mathrm{C}), 139.6(\mathrm{C}), 141.2(\mathrm{C})$, 141.9 (C), $147.6(\mathrm{CH}), 152.3$ (C), 155.9 (C) ppm. MS (ESI- TOF) $m / z$ (\%): $392.09\left(\mathrm{M}^{+}+\mathrm{H}, 100\right)$. HRMS (ESI-TOF): calcd for $\mathrm{C}_{21} \mathrm{H}_{18} \mathrm{~N}_{3} \mathrm{OS}_{2}\left[\mathrm{M}^{+}+\mathrm{H}\right]$ 392.0886, found 392.0894. Anal. Calcd for $\mathrm{C}_{21} \mathrm{H}_{17} \mathrm{~N}_{3} \mathrm{OS}_{2}$ : C, $64.42 ; \mathrm{H}, 4.38 ; \mathrm{N}, 10.73 ; \mathrm{S}, 16.38 \%$. Found: C 64.24; H, 4.26; N, 11.03; S, 15.97\%.

4.1.2.10. 1-[3-(Trifluoromethyl)phenyl]-3-[3-(thieno[3,2b]pyridin-7-ylthio)phenyl]urea (4g). From 3-(thieno[3,2-b]pyridine7-ylthio)aniline (100 $\mathrm{mg}, 0.387 \mathrm{mmol}$ ) and 3-(trifluoromethyl)phenylisocyanate $(72.4 \mathrm{mg}, 53.4 \mu \mathrm{L}, 0.387 \mathrm{mmol}$ ) compound $\mathbf{4 g}$ was isolated as a beige solid (86.0 mg, 50\%) Mp $138-140{ }^{\circ} \mathrm{C} .{ }^{1} \mathrm{H}$ NMR (DMSO- $d_{6}, 400 \mathrm{MHz}$ ): 6.93 (d, J=4.8 Hz, 6"'-H), 7.23 (br d, $1 \mathrm{H}), 7.30(\mathrm{br} \mathrm{d}, 1 \mathrm{H}), 7.42-7.57(\mathrm{~m}, 4 \mathrm{H}), 7.60(\mathrm{~d}, J=5.6 \mathrm{~Hz}, 1 \mathrm{H})$, 7.80 (br s, $1 \mathrm{H},), 7.96$ (br s, $1 \mathrm{H},), 8.16(\mathrm{~d}, J=5.6 \mathrm{~Hz}, 1 \mathrm{H}), 8.53(\mathrm{~d}$, $\left.J=4.8 \mathrm{~Hz}, 5^{\prime \prime \prime}-\mathrm{H}\right), 9.03(\mathrm{~s}, \mathrm{NH}), 9.09(\mathrm{~s}, \mathrm{NH}) .{ }^{13} \mathrm{C}$ NMR (DMSO-d 6 , 100.6 MHz): 114.30 (q, J = 3.9 Hz, $\left.2^{\prime}-\mathrm{CH}\right), 116.53\left(6^{\prime \prime \prime}-\mathrm{CH}\right), 118.30$ $\left(\mathrm{q}, J=3.9 \mathrm{~Hz}, 4^{\prime}-\mathrm{CH}\right), 119.66(\mathrm{CH}), 122.00(\mathrm{CH}), 123.10(\mathrm{CH})$, $123.8\left(\mathrm{q}, J=273.0 \mathrm{~Hz}, \mathrm{CF}_{3}\right), 125.0(\mathrm{CH}), 127.4(\mathrm{CH}), 128.86(\mathrm{C})$, 129.5 (q, $\left.J=31 \mathrm{~Hz}, \mathrm{CCF}_{3}\right), 130.0(\mathrm{CH}), 130.5(\mathrm{CH}), 130.78(\mathrm{C})$, 132.1 (CH), 140.30 (C), 140.90 (C), 142.00 (C), 147.50 (5'"'-CH), 152.39 (C), 155.79 (C) ppm. MS (ESI): $446.25\left(\mathrm{M}^{+}+\mathrm{H}, 100\right)$. Anal. Calcd for $\mathrm{C}_{21} \mathrm{H}_{14} \mathrm{~F}_{3} \mathrm{~N}_{3} \mathrm{OS}_{2}$ : C, 56.62; $\mathrm{H}, 3.17 ; \mathrm{N}, 9.43 ; \mathrm{S}, 14.40 \%$. Found: C 56.31; H, 3.28; N, 9.70; S, $14.80 \%$.

4.1.2.11. 1-[4-Chloro-3-(trifluoromethyl)phenyl]-3-[3-(thieno[3,2-b]pyridin-7-ylthio)phenyl]urea (4h). From 3-(thieno[3,2-b]pyridine-7-ylthio)aniline $\quad(78.6 \mathrm{mg}, \quad 0.304 \mathrm{mmol})$ and 4-chloro-3-(trifluoromethyl)isocyanate $\quad(67.4 \mathrm{mg}, \quad 0.304 \mathrm{mmol})$ compound $4 \mathrm{~h}$ was isolated as a beige solid $(87.6 \mathrm{mg}, 60 \%)$. Mp 196-198 ${ }^{\circ} \mathrm{C}$. ${ }^{1} \mathrm{H}$ NMR (DMSO- $d_{6}, 400 \mathrm{MHz}$ ): 6.93 (d, $J=4.8 \mathrm{~Hz}$, $6^{\prime \prime \prime}-\mathrm{H}$ ), 7.23 (br d, 1H), 7.43 (apparent t, J=8.0 Hz, 4"-H), 7.54$7.64(4 \mathrm{H}, \mathrm{m}), 7.77$ (apparent t, $\left.J=2.0 \mathrm{~Hz}, 2^{\prime \prime}-\mathrm{H}\right), 8.06(\mathrm{~d}, J=2.4 \mathrm{~Hz}$, $\left.2^{\prime}-\mathrm{H}\right), 8.16(\mathrm{~d}, J=5.2 \mathrm{~Hz}, 1 \mathrm{H}), 8.52\left(\mathrm{~d}, J=4.8 \mathrm{~Hz}, 5^{\prime \prime \prime}-\mathrm{H}\right), 9.07(\mathrm{~s}$, $\mathrm{NH}), \quad 9.20(\mathrm{~s}, \mathrm{NH}) .{ }^{13} \mathrm{C}$ NMR (DMSO- $\left.d_{6}, 100.6 \mathrm{MHz}\right): 116.6$ (6'"'-CH), 116.9 (q, J=6.0 Hz, 2'-CH), $119.7(\mathrm{CH}), 122.5(\mathrm{C}), 122.8$ $\left(\mathrm{q}, J=272.6 \mathrm{~Hz}, \mathrm{CF}_{3}\right), 123.2(\mathrm{CH}), 123.3(\mathrm{CH}), 125.0(\mathrm{CH}), 126.7(\mathrm{q}$, $\left.J=30.0 \mathrm{~Hz}, \mathrm{CCF}_{3}\right), 127.5(\mathrm{CH}), 128.9(\mathrm{C}), 130.50\left(4^{\prime \prime}-\mathrm{CH}\right), 130.8(\mathrm{C})$, $132.0(\mathrm{CH}), 132.1(\mathrm{CH}), 139.1$ (C), 140.8 (C), 141.9 (C), 147.6 (5'"CH), 152.3 (C), 155.9 (C) ppm. MS (ESI): $\mathrm{m} / z(\%) 480.17\left(\mathrm{M}^{+}{ }^{35} \mathrm{Cl}\right.$ $+\mathrm{H}, 100), 482.17\left(\mathrm{M}^{+37} \mathrm{Cl}+\mathrm{H}, 30\right)$ Anal. Calcd for $\mathrm{C}_{21} \mathrm{H}_{13} \mathrm{ClF}_{3} \mathrm{~N}_{3} \mathrm{OS}_{2}$ : C, 52.55; H, 2.73; N, 8.76; S, 13.36\%. Found: C 52.24; H, 2.74; N, 8.62; S, $13.27 \%$.

4.1.2.12. 1-Phenyl-3-[4-(thieno[3,2-b]pyridin-7-ylthio)phenyl]urea (5a). From compound 2 c $(100 \mathrm{mg}, 0.370 \mathrm{mmol})$ and phenylisocyanate $(44.0 \mathrm{mg}$ ) compound $\mathbf{5 a}$ was isolated as a yellow solid (90.0 mg, 65\%). Mp 92-93 ${ }^{\circ} \mathrm{C} .{ }^{1} \mathrm{H}$ NMR (DMSO- $\left.d_{6}, 300 \mathrm{MHz}\right): \delta$ $6.73(\mathrm{~d}, J=5.2 \mathrm{~Hz}, 1 \mathrm{H}), 6.96-7.01(\mathrm{~m}, 1 \mathrm{H}), 7.26-7.29(\mathrm{~m}, 2 \mathrm{H}), 7.44-$ $7.47(\mathrm{~m}, 2 \mathrm{H}), 7.55-7.62(\mathrm{~m}, 5 \mathrm{H}), 8.15(\mathrm{~d}, J=5.4 \mathrm{~Hz}, 1 \mathrm{H}), 8.51(\mathrm{br} \mathrm{s}$, $1 \mathrm{H}), 8.77$ (br s, $1 \mathrm{H}, \mathrm{NH}$ ), 9.02 (br s, NH) ppm. ${ }^{13} \mathrm{C}$ NMR (DMSO-d $75.4 \mathrm{MHz}): \delta 115.1(\mathrm{CH}), 118.4 \quad(2 \times \mathrm{CH}), 118.8$ (C), 119.3 $(2 \times \mathrm{CH}), 122.2(\mathrm{CH}), 125.0(\mathrm{CH}), 128.8(2 \times \mathrm{CH}), 131.7(\mathrm{CH})$, $136.2(2 \times \mathrm{CH}), 139.4(\mathrm{C}), 141.9(\mathrm{C}), 143.8(\mathrm{C}), 147.4(\mathrm{CH}), 152.3$ (C), 155.6 (C) ppm. MS (ESI- TOF) $m / z$ (\%): $378.07\left(\mathrm{M}^{+}+\mathrm{H}, 100\right)$. HRMS (ESI-TOF): calcd for $\mathrm{C}_{20} \mathrm{H}_{16} \mathrm{~N}_{3} \mathrm{OS}_{2}\left[\mathrm{M}^{+}+\mathrm{H}\right]$ 378.0729, found 378.0720. Anal. Calcd for $\mathrm{C}_{20} \mathrm{H}_{15} \mathrm{~N}_{3} \mathrm{OS}_{2}$ : C, 63.64; $\mathrm{H}, 4.01 ; \mathrm{N}$, 11.13 ; S, 16.99\%. Found: C 63.82; H, 4.15; N, 10.92; S, 16.59\%.

4.1.2.13. 1-(4-Methoxyphenyl)-3-[4-(thieno[3,2-b]pyridin-7ylthio)phenyl]urea (5b). From compound 2c $(60.0 \mathrm{mg}$, $0.230 \mathrm{mmol}$ ) and 4-methoxyphenylisocyanate (35.0 mg, compound $\mathbf{5 b}$ was isolated as a yellow solid $(65.0 \mathrm{mg}, 70 \%)$. Mp 195$196{ }^{\circ} \mathrm{C} .{ }^{1} \mathrm{H}$ NMR (DMSO-d, $400 \mathrm{MHz}$ ): $\delta 3.71$ (s, 3H, OMe), 6.72 $(\mathrm{d}, J=5.2 \mathrm{~Hz}, 1 \mathrm{H}), 6.87(\mathrm{~d}, J=8.8 \mathrm{~Hz}, 2 \mathrm{H}), 7.36(\mathrm{~d}, J=8.8 \mathrm{~Hz}, 2 \mathrm{H})$, $7.55(\mathrm{~d}, J=8.8 \mathrm{~Hz}, 2 \mathrm{H}), 7.58(\mathrm{~d}, J=5.6 \mathrm{~Hz}), 7.61(\mathrm{~d}, J=8.8 \mathrm{~Hz}, 2 \mathrm{H})$, 
$8.14(\mathrm{~d}, J=5.6 \mathrm{~Hz}, 1 \mathrm{H}), 8.46(\mathrm{~d}, J=5.2 \mathrm{~Hz}, 1 \mathrm{H}), 8.57(\mathrm{br} \mathrm{s}, 1 \mathrm{H}, \mathrm{NH})$ 8.93 (br s, $1 \mathrm{H}, \mathrm{NH}$ ) ppm. ${ }^{13} \mathrm{C}$ NMR (DMSO-d, $\left.100.6 \mathrm{MHz}\right): \delta 55.2$ (OMe), $114.1(2 \times \mathrm{CH}), 114.9(\mathrm{CH}), 118.5(\mathrm{C}), 119.2(2 \times \mathrm{CH})$, $120.2(2 \times \mathrm{CH}), 124.9(\mathrm{CH}), 129.4(\mathrm{C}), 131.7(\mathrm{CH}), 132.3(\mathrm{C}), 136.2$ $(2 \times \mathrm{CH}), 142.1(\mathrm{C}), 143.9(\mathrm{C}), 147.4(\mathrm{CH}), 152.5(\mathrm{C}), 154.7(\mathrm{C})$, 155.7 (C) ppm. MS (ESI- TOF) $m / z$ (\%): $408.08\left(\mathrm{M}^{+}+\mathrm{H}, 100\right)$. HRMS (ESI-TOF): calcd for $\mathrm{C}_{21} \mathrm{H}_{18} \mathrm{~N}_{3} \mathrm{O}_{2} \mathrm{~S}_{2}\left[\mathrm{M}^{+}+\mathrm{H}\right]$ 408.0835, found 408.0833. Anal. Calcd for $\mathrm{C}_{21} \mathrm{H}_{17} \mathrm{~N}_{3} \mathrm{O}_{2} \mathrm{~S}_{2}$ : C, 61.89; $\mathrm{H}, 4.20 ; \mathrm{N}$, $10.31 ;$ S, $15.74 \%$. Found: C $62.01 ; \mathrm{H}, 3.94 ; \mathrm{N}, 10.60 ; \mathrm{S}, 15.32 \%$.

4.1.2.14. 1-(4-Cyanophenyl)-3-[4-(thieno[3,2-b]pyridin-7-ylthio)phenyl]urea (5c). From compound $2 \mathrm{c}(120 \mathrm{mg}, 0.460 \mathrm{mmol})$ and 4-cyanophenylisocyanate $(66.0 \mathrm{mg})$, compound $\mathbf{5 c}$ was isolated as a yellow solid $(120 \mathrm{mg}, 65 \%)$. Mp $154-155^{\circ} \mathrm{C} .{ }^{1} \mathrm{H}$ NMR (DMSO- $d_{6}$, $400 \mathrm{MHz}): \delta 6.74(\mathrm{~d}, J=5.2 \mathrm{~Hz}, 1 \mathrm{H}), 7.57(\mathrm{~d}, J=5.6 \mathrm{~Hz}, 1 \mathrm{H}), 7.58$ (d, $J=8.8 \mathrm{~Hz}, 2 \mathrm{H}), 7.63-7.65(\mathrm{~m}, 4 \mathrm{H}), 7.74(\mathrm{~d}, J=8.8 \mathrm{~Hz}, 2 \mathrm{H}), 8.15$ $(\mathrm{d}, J=5.6 \mathrm{~Hz}, 1 \mathrm{H}), 8.47(\mathrm{~d}, J=5.2 \mathrm{~Hz}, 1 \mathrm{H}), 9.20$ (br s, $1 \mathrm{H}, \mathrm{NH}$ ), 9.29 (br s, $1 \mathrm{H}, \mathrm{NH}$ ) ppm. ${ }^{13} \mathrm{C}$ NMR (DMSO-d $6,100.6 \mathrm{MHz}$ ): $\delta$ 103.6 (C), $115.1(\mathrm{CH}), 118.2(2 \times \mathrm{CH}), 118.4(\mathrm{C}), 119.2(\mathrm{C}), 119.6$ $(2 \times \mathrm{CH}), 125.0(\mathrm{CH}), 129.5(\mathrm{C}), 131.8(\mathrm{CH}), 133.3(2 \times \mathrm{CH}), 136.1$ $(2 \times \mathrm{CH}), 141.2(\mathrm{C}), 143.6(\mathrm{C}), 143.9(\mathrm{C}), 147.5(\mathrm{CH}), 151.9(\mathrm{C})$, 155.7 (C) ppm. MS (ESI- TOF) $m / z(\%): 403.07\left(\mathrm{M}^{+}+\mathrm{H}, 100\right)$ HRMS (ESI-TOF): calcd for $\mathrm{C}_{21} \mathrm{H}_{15} \mathrm{~N}_{4} \mathrm{OS}_{2}\left[\mathrm{M}^{+}+\mathrm{H}\right]$ 403.0682, found 403.0681. Anal. Calcd for $\mathrm{C}_{21} \mathrm{H}_{14} \mathrm{~N}_{4} \mathrm{OS}_{2}$ : C, 62.67; $\mathrm{H}, 3.51 ; \mathrm{N}$, $13.92 ; \mathrm{S}, 15.93 \%$. Found: C 62.85; H, 3.73; N, 13.57; S, 15.55\%.

4.1.2.15. 1-[3-(Trifluoromethyl)phenyl]-3-[4-(thieno[3,2b]pyridin-7-ylthio)phenyl]urea (5d). From 4-(thieno[3,2-b]pyridine7-ylthio)aniline $(90.8 \mathrm{mg}, 0.351 \mathrm{mmol}$ ) and 3-(trifluoromethyl) phenyl-isocyanate $(65.8 \mathrm{mg}, 0.351 \mathrm{mmol}, 48.4 \mu \mathrm{L})$ compound $\mathbf{5 d}$ was isolated as a colourless solid (86.0 mg, 55\%). Mp $162-164^{\circ} \mathrm{C}$. ${ }^{1} \mathrm{H}$ NMR (DMSO-d $d_{6}, 400 \mathrm{MHz}$ ): $6.74\left(\mathrm{~d}, J=4.8 \mathrm{~Hz}, 6^{\prime \prime \prime}-\mathrm{H}\right), 7.33(\mathrm{br}$ d, $4^{\prime}-\mathrm{H}$ ), 7.52 (apparent $\left.\mathrm{t}, J=8.0 \mathrm{~Hz}, 5^{\prime}-\mathrm{H}\right), 7.56-7.61(\mathrm{~m}, 4 \mathrm{H})$, $7,65(\mathrm{~d}, J=9.0 \mathrm{~Hz}, 2 \mathrm{H}), 8.01\left(\right.$ br s, $\left.2^{\prime}-\mathrm{H}\right), 8.15(\mathrm{~d}, J=5.6 \mathrm{~Hz}, 1 \mathrm{H})$, $8.47\left(\mathrm{~d}, J=4.8 \mathrm{~Hz}, 5^{\prime \prime \prime}-\mathrm{H}\right), 9.13(\mathrm{~s}, \mathrm{NH}), 9.14(\mathrm{~s}, \mathrm{NH}) .{ }^{13} \mathrm{C} \mathrm{NMR}$ (DMSO- $\left.d_{6}, 100.6 \mathrm{MHz}\right): 114.3\left(\mathrm{q}, J=4.0 \mathrm{~Hz}, 2^{\prime}-\mathrm{CH}\right), 115.1\left(6^{\prime \prime \prime}-\mathrm{CH}\right)$, $118.4\left(\mathrm{q}, J=4.0 \mathrm{~Hz}, 5^{\prime}-\mathrm{CH}\right), 119.36(\mathrm{C}), 119.63(2 \times \mathrm{CH}), 122.0$ (CH), $122.83(\mathrm{C}), 124.2$ (q, J = 271.6 Hz, $\left.\mathrm{CF}_{3}\right), 125.0(\mathrm{CH}), 129.5$ (q, $\left.J=31.2 \mathrm{~Hz}, \mathrm{CCF}_{3}\right), 129.6(\mathrm{C}), 130.0\left(4^{\prime}-\mathrm{CH}\right), 131.8(\mathrm{CH}), 136.1$ $(2 \times \mathrm{CH}), 140.3(\mathrm{C}), 141.5(\mathrm{C}), 143.7(\mathrm{C}), 147.5\left(5^{\prime \prime \prime}-\mathrm{CH}\right), 152.3(\mathrm{C})$, 155.7 (C) ppm. MS (ESI) $m / z$ (\%): $446.25\left(\mathrm{M}^{+}+\mathrm{H}, 100\right)$. Anal. Calcd for $\mathrm{C}_{21} \mathrm{H}_{14} \mathrm{~F}_{3} \mathrm{~N}_{3} \mathrm{OS}_{2}$ : C, 56.62; $\mathrm{H}, 3.17 ; \mathrm{N}, 9.43 ; \mathrm{S}, 14.40 \%$. Found: $\mathrm{C}$ 56.30; H, 3.26; N, 9.73; S, $14.78 \%$.

4.1.2.16. 1-(4-Chloro-3-(trifluoromethyl)phenyl)-3-[4-(thieno[3,2-b]pyridin-7-ylthio)phenyl]urea (5e). From 4-(thieno[3,2b]pyridine-7-ylthio)aniline (101.8 $\mathrm{mg}, 0.394 \mathrm{mmol}$ ) and 4-chloro3-(trifluoromethyl)phenyl-isocyanate $\quad(87.3 \mathrm{mg}, \quad 0.394 \mathrm{mmol})$ compound 5e was isolated as a light yellow solid (136 mg, 72\%). Mp 224-226 ${ }^{\circ} \mathrm{C} .{ }^{1} \mathrm{H}$ NMR (DMSO- $\left.d_{6}, 400 \mathrm{MHz}\right): 6.74(\mathrm{~d}, J=4.8 \mathrm{~Hz}$, $\left.6^{\prime \prime \prime}-\mathrm{H}\right), \quad 7.56-7.66 \quad(\mathrm{~m}, \quad 7 \mathrm{H}), \quad 8.1 \quad\left(\mathrm{~d}, \quad J=2.4 \mathrm{~Hz}, \quad 2^{\prime}-\mathrm{H}\right), \quad 8.15$ (d, $J=5.2 \mathrm{~Hz}, 1 \mathrm{H}), 8.47$ (d, $\left.J=4.8 \mathrm{~Hz}, 5^{\prime \prime \prime}-\mathrm{H}\right), 9.18$ (s, NH), 9.25 $(\mathrm{s}, \quad \mathrm{NH}) .{ }^{13} \mathrm{C}$ NMR (DMSO- $\left.d_{6}, 100.6 \mathrm{MHz}\right): 115.1 \quad\left(6^{\prime \prime \prime}-\mathrm{CH}\right)$, 117.0 (q, $\left.J=6.0 \mathrm{~Hz}, 2^{\prime}-\mathrm{CH}\right), 119.7(2 \times \mathrm{CH}), 122.5$ (C) 122.6 (C) $122.8\left(\mathrm{q}, J=272.6 \mathrm{~Hz}, \mathrm{CF}_{3}\right), 123.3(\mathrm{CH}), 125.0(\mathrm{CH}), 126.7$ (q, $\left.J=30.2 \mathrm{~Hz}, C^{2} \mathrm{CF}_{3}\right), 129.5(\mathrm{C}), 131.8(\mathrm{CH}), 132.0(\mathrm{CH}), 136.1$ $(2 \times \mathrm{CH}) 139.1$ (C), 141.3 (C), $143.6(\mathrm{C}), 147.4\left(5^{\prime \prime \prime}-\mathrm{CH}\right), 152.2(\mathrm{C})$, 155.7 (C) ppm. MS (ESI) $\mathrm{m} / z(\%): 480.17\left(\mathrm{M}^{+}{ }^{35} \mathrm{Cl}+\mathrm{H}, 100\right), 482.17$ $\left(\mathrm{M}^{+}{ }^{37} \mathrm{Cl}+\mathrm{H}, 29\right)$. Anal. Calcd for $\mathrm{C}_{21} \mathrm{H}_{13} \mathrm{ClF}_{3} \mathrm{~N}_{3} \mathrm{OS}_{2}$ : C, 52.55; $\mathrm{H}$, 2.73 ; N, 8.76; S, 13.36\%. Found: C 52.25; H, 2.75; N, 8.66; S, $13.46 \%$.

\subsection{VEGFR-2 kinase inhibition assay}

The compounds were assessed for VEGFR-2 inhibitory activity using the Z'-LYTE-Tyr1 Peptide assay kit (Invitrogen, Cat. PV3190) and according to the procedures recommended by the manufacturer. ${ }^{12}$ Briefly, assays were performed in a total of $20 \mu \mathrm{L}$ in 384-well plates using fluorescence resonance energy transfer technology. A Tyr1 substrate (coumarin-fluorescein double-labeled peptide) at $1 \mu \mathrm{M}$ was incubated for $1 \mathrm{~h}$ with $4 \mu \mathrm{g} / \mathrm{mL}$ VEGFR-2, $10 \mu \mathrm{M}$ ATP, and inhibitors at room temperature in $50 \mathrm{mM}$ Hepes/ $\mathrm{NaOH}$ (pH 7.5), $10 \mathrm{mM} \mathrm{MgCl}_{2}, 2 \mathrm{mM} \mathrm{MnCl}_{2}, 2.5 \mathrm{mM} \mathrm{DTT}$, $0.10 \mathrm{mM}$ orthovanadate, and $0.01 \%$ bovine serum albumin (BSA). Inhibitors were added to the wells with $4 \%$ DMSO added as solvent. The wells were incubated at $25^{\circ} \mathrm{C}$ for $1 \mathrm{~h}$ and $5 \mu \mathrm{L}$ of development reagent was added to each well. After a second incubation of $1 \mathrm{~h}$ the stop reagent was added to each well. Using a Biotek FLX800 micro-plate the fluorescence was read at $445 \mathrm{~nm}$ and $520 \mathrm{~nm}$ (excitation $400 \mathrm{~nm}$ ), and Gen5 ${ }^{\mathrm{TM}}$ Software was used for data analysis. The validation assay was performed using Staurosporine that present an $\mathrm{IC}_{50}$ value $6 \mathrm{nM}$ that compares to the one reported in the literature. ${ }^{16}$

\subsection{Molecular docking protocol}

VEGFR-2 crystal structure (PDB: 3VHE) was extracted from the Protein Data Bank (PDB) (http://www.rcsb.org). The co-crystallized ligand was extracted from the PDB file, and AutoDockTools was used to assign polar hydrogens and Gasteiger charges. AutoGrid4 was used to create affinity grid maps for all atom types. The affinity grids enclosed a volumetric space of $100 \AA$ by $100 \AA$ by $100 \AA$, with $0.375 \AA$ spacing, centered on the coordinates $x=86.3, y=51.2$, $z=48.3$. AutoDock4 (version 4.1 ) with the Lamarckian genetic algorithm was used with the following docking parameters: 100 docking runs, population size of 200 , random starting position and conformation, translation step ranges of $2.0 \AA$, mutation rate of 0.02 , crossover rate of 0.8 , local search rate of $0.06,2.5$ and 25 million energy evaluations. ${ }^{23}$ Docked conformations were clustered using a tolerance of $2.0 \AA$ RMSD. The entire virtual experiment was performed on a cluster of 64 AMD $2.0 \mathrm{GHz}$ processor, using software MOLA. ${ }^{24}$ The 3D compound-protein docking poses were analyzed manually using AutoDockTools, and Figure 1 was prepared using the software PyMOL. ${ }^{18}$

\subsection{Biological assays}

\subsubsection{HUVECs culture}

HUVECs were obtained from the Science Cell Research Labs (San Diego, CA, USA). HUVECs were harvested in gelatin-coated culture plates in M199 medium (Sigma-Aldrich, Sintra, Portugal) supplemented with $20 \%$ fetal bovine serum (FBS), $1 \%$ penicillin/streptomycin (Invitrogen Life Technologies, Scotland, UK), 0.01\% heparin (Sigma-Aldrich), and $30 \mathrm{mg} / \mathrm{mL}$ endothelial cell growth supplement (Biomedical Technologies Inc., MA, USA) and maintained at $37{ }^{\circ} \mathrm{C}$ in a humidified atmosphere containing $5 \% \mathrm{CO}_{2}$. The tested compounds were dissolved in DMSO and added to cell cultures at a concentration of $0.1-10 \mu \mathrm{M}$. Treatments were performed during $24 \mathrm{~h}$ in medium supplemented with $2 \% \mathrm{FBS}, 1 \%$ penicillin/ streptomycin, and $60 \mathrm{ng} / \mathrm{mL}$ of the vascular endothelial growth factor (VEGF) (Sigma-Aldrich, Portugal). Control cells were treated with vehicle ( $0.1 \%$ DMSO).

\subsubsection{HUVECs viability assay}

HUVECs were seeded $\left(2 \times 10^{5}\right.$ cells $\left./ \mathrm{mL}\right)$ in 96 -well plate, allowed to grow for $24 \mathrm{~h}$ and then incubated with different dilutions of tested compounds at a range concentration between 0.1 and $10 \mu \mathrm{M}$ or control (0.1\% DMSO), in the presence of VEGF, for $24 \mathrm{~h}$. After the incubation period, cells were washed with PBS and their viability was assessed using Cell Titer 96 Aqueous ONE Solution Reagent MTS [3-(4,5-dimethylthiazol-2-yl)-5-(3-carboxymethoxyphenyl)-2-(4-sulfophenyl)-2H-tetrazolium] colorimetric assay (Promega, Madison, USA), according to the 
instructions provided by the manufacturer and as previously described. ${ }^{25}$ Optical density was measured at $492 \mathrm{~nm}$.

\subsubsection{HUVECs proliferation assay}

HUVECs $\left(6 \times 10^{4}\right.$ cells $\left./ \mathrm{mL}\right)$ were grown during $24 \mathrm{~h}$ and then incubated with compounds at $0.1-10 \mu \mathrm{M}$ or control ( $0.1 \%$ DMSO), in the presence of VEGF, for $24 \mathrm{~h}$. Cells were also incubated with 5 '-bromodeoxyuridine (BrdU) solution at a final concentration of $0.01 \mathrm{mM}$ during the treatment period. Optical density of proliferating cells (positive for BrdU) after ELISA assay using anti-BrdUspecific antibodies (Roche Diagnostics, Mannheim, Germany) was evaluated at the microplate reader according to the manufacturer's instructions and as previously reported. ${ }^{26}$ Results were expressed as percentage of control (100\%).

\subsubsection{HUVECs migration assay: wound-healing}

HUVECs were seeded in a 24 -well plates pre-coated with $0.1 \%$ gelatin and were allowed to grow to $100 \%$ confluence. Cell culture were injured by a $10 \mu \mathrm{L}$ tip, cells were washed twice with PBS, and then incubated with fresh medium containing VEGF with or without the compounds in study at different concentrations for $24 \mathrm{~h}$. Cell migration to the damaged area was then visualized and photographed on a phase contrast microscope (Nikon) at a magnification of $100 \times .^{25}$ Inhibition percentage was expressed as percentage of the control (100\%).

\subsubsection{HUVECs capillary-like tube formation assay}

Matrige ${ }^{\circledR}$ basement membrane matrix (growth factor reduced) (Corning, USA) was thawed at $4{ }^{\circ} \mathrm{C}$, pipetted into pre-chilled 24well plates $(200 \mu \mathrm{L}$ matrigel/well $)$ and incubated at $37{ }^{\circ} \mathrm{C}$ for $30 \mathrm{~min}$. Then HUVECs $\left(8 \times 10^{4}\right.$ cells $\left./ \mathrm{mL}\right)$ were added to matrigel coated plates, followed by addition of various concentrations of compounds in study with VEGF $(60 \mathrm{ng} / \mathrm{mL})$. After $24 \mathrm{~h}$ of incubation with $5 \% \mathrm{CO} 2$ at $37{ }^{\circ} \mathrm{C}$, the number of capillary-like tube formation of each well was photographed using a phase-contrast microscope (Nikon, UK) at $100 \times$ magnifications. Tube formation was quantitated by manual counting the number of branch points. ${ }^{25}$ All experiments were done in triplicate. Inhibition percentage was expressed as percentage of control (100\%).

\subsubsection{Western blotting analysis}

In brief, proteins were isolated from HUVEC lysates using RIPA (Chemicon International, CA, USA) and $20 \mu \mathrm{g}$ of protein were separated by $8 \%$ SDS-PAGE and transferred to Hybond nitrocellulose membrane (Amersham, Arlington, VA, USA). Membranes were then incubated with primary antibodies including phosphorylated (activated) VEGFR-2 (Santa Cruz Biotechnology, CA, USA), total VEGFR2 (Cell Signalling, MA, USA) and $\beta$-actin (Abcam, Cambridge, UK). After overnight incubation at $4^{\circ} \mathrm{C}$, membranes were washed with TBST and incubated with secondary antibodies at room temperature for $1 \mathrm{~h}$. Immunoreactive bands were then visualized by the enhanced chemiluminescence detection system (ECL kit, Amersham, Arlington, USA). ${ }^{26}$

\subsubsection{Statistical analyses}

All experiments were performed at least in three independent experiments. Data are expressed as mean \pm SEM. The significance of the differences between the means observed was evaluated using the one-way ANOVA followed by Bonferroni test. $p<0.05$ was considered statistically significant.

\section{Acknowledgments}

To the Foundation for Science and Technology (FCT-Portugal) for financial support through the NMR Portuguese network (Bruker 400 Avance III-Univ Minho). FCT and FEDER (European Fund for Regional Development)-COMPETE/QREN/EU for financial support through the research unities PEst-C/QUI/UI686/2013-2014, PEstOE/SAU/UI0038/2013 and 2014 and PEst-OE/AGR/UI0690/2013 and 2014, the research project PTDC/QUI-QUI/111060/2009, the PhD grant attributed to V.M. (SFRH/BD/77373/2011) and the post-Doctoral grant attributed to R.C.C. (SFRH/BPD/68344/2010), also financed by the POPH and FSE.

\section{References and notes}

1. Strawn, L. M.; McMahon, G.; App, H.; Schreck, R.; Ku-chler, W. R.; Longhi, M. P.; Hui, T. H.; Tang, C.; Levitzki, A.; Gazit, A.; Chen, I.; Keri, G.; Orfi, L.; Risau, W.; Flamme, I.; Ullrich, A.; Hirth, K. P.; Shawver, L. K. Cancer Res. 1996, 56, 3540.

2. Baka, S.; Clamp, A. R.; Jayson, G. C. Expert Opin. Ther. Targets 2006, 10, 867.

3. Carmeliet, P.; Jain, R. K. Nature 2011, 473, 298.

4. Liu, Y.; Gray, N. S. Nat. Chem. Biol. 2006, 2, 358.

5. Eichholz, A.; Merchant, S.; Gaya, A. M. OncoTargets Ther. 2010, 3, 69.

6. Backes, A.; Zech, B.; Felber, B.; Klebl, B.; Müller, G. Expert Opin. Drug Dis. 2008, 3, 1427.

7. Wilhelm, S. M.; Carter, C.; Tang, L. Y.; Wilkie, D.; McNabola, A.; Rong, H.; Chen, C.; Zhang, X.; Vincent, P.; McHugh, M.; Cao, Y.; Shujath, J.; Gawlak, S.; Eveleigh, D.; Rowley, B.; Liu, L.; Adnane, L.; Lynch, M.; Auclair, D.; Taylor, I.; Gedrich, R.; Voznesensky, A.; Riedl, B.; Post, L. E.; Bollag, G.; Trail, P. A. Cancer Res. 2004, 64, 7099.

8. Hasegawa, M.; Naohiko, N.; Yoshiaki, W.; Kazuya, K.; Harris, P. A. H.; Sato, H.; Mori, I.; West, R. I.; Shibahara, M.; Toyoda, H.; Wang, L.; Nolte, R. T.; Veal, J. M.; Cheung, M. J. Med. Chem. 2007, 50, 4453.

9. Oguro, Y.; Miyamoto, N.; Okada, K.; Takagi, T.; Iwata, H.; Awazu, Y.; Miki, H.; Hori, A.; Kamiyama, K.; Imamura, S. Bioorg. Med. Chem. 2010, 18, 7260.

10. Soares, P.; Costa, R.; Froufe, H. J. C.; Calhelha, R. C.; Peixoto, D.; Ferreira, I. C. F. R.; Abreu, R. M. V.; Soares, R.; Queiroz, M.-J. R. P. BioMed. Res. Int. 2013. Article ID154856, 9 pages.

11. (a) Claridge, S.; Raeppel, F.; Granger, M.-C.; Bernstein, N.; Saavedra, O.; Zhan, L.; Llewellyn, D.; Wahhab, A.; Deziel, R.; Rahil, J.; Beaulieu, N.; Nguyen, H.; Dupont, I.; Barsalou, A.; Beaulieu, C.; Chute, I.; Gravel, S.; Robert, M.-F.; Lefebvre, S.; Dubay, M.; Pascal, R.; Gillespie, J.; Jin, Z.; Wang, J.; Besterman, J. M.; MacLeod, A. R.; Vaisburg, A. Bioorg. Med. Chem. Lett. 2008, 18, 2793; (b) Barker, J. M.; Huddleston, P. R.; Keenan, G. J. J. Chem. Res. 1982, 158, 1726.

12. http://tools.invitrogen.com, last accessed 15 May 2012.

13. Oguro, Y.; Miyamoto, N.; Takagi, T.; Okada, K.; Awazu, Y.; Miki, H.; Imamura, S. Bioorg. Med. Chem. 2010, 18, 7150.

14. Saavedra, O.; Claridge, S.; Zhan, L.; Raeppel, F.; Granger, M.-C.; Raeppel, S.; Mannion, M.; Gaudette, F.; Zhou, N.; Isakovic, L.; Bernstein, N.; Déziel, R.; Nguyen, H.; Beaulieu, N.; Beaulieu, C.; Dupont, I.; Wang, J.; Macleod, R.; Besterman, J. M.; Vaisburg, A. Bioorg. Med. Chem. 2009, 19, 6836.

15. Miyazaki, Y.; Matsunaga, S.; Tang, J.; Maeda, Y.; Nakano, M.; Philippe, R. J.; Nolte, R. T. Bioorg. Med. Chem. 2005, 15, 2203.

16. Staurosporine $\mathrm{IC}_{50}$ reported by Invitrogen, using the same FRET-based VEGFR-2 enzymatic kit used for this study, http://tools.invitrogen.com, last accessed 15 May 2012.

17. Cremlyn, R. J. An Introduction to Organosulfur Chemistry; John Wiley and Sons: Chichester, 1996.

18. The Pymol Molecular Graphics System, Version 1.3, Schrödinger LLC, 2010.

19. Yang, F.; Brown, C.; Buettner, R.; Hedvat, M.; Starr, R.; Scuto, A.; Schroeder, A.; Jensen, M.; Jove, R. Mol. Cancer Ther. 2010, 9, 953.

20. (a) Shibuya, M. Endothelium 2006, 13, 63; (b) Bazmara, H.; Soltani, M.; Sefidgar, M.; Bazargan, M.; Mousavi Naeenian, M.; Rahmim, A. PLoS One 2015, 10, e0128878.

21. Jane, E. P.; Premkumar, D. R.; Pollack, I. F. J. Pharmacol. Exp. Ther. 2006, 319, 1070.

22. Qi, J. H.; Claesson-Welsh, L. Exp. Cell Res. 2001, 263, 173.

23. Morris, G. M.; Huey, R.; Lindstrom, W.; Sanner, M. F.; Belew, R. K.; Goodsell, D. S.; Olson, A. J. J. Comput. Chem. 2009, 30, 2785.

24. Abreu, R. M. V.; Froufe, H. J. C.; Queiroz, M.-J. R. P.; Ferreira, I. C. F. R. J. Cheminf. 2010, 2. article 10,6 pages.

25. Costa, R.; Carneiro, A.; Rocha, A.; Pirraco, A.; Falcão, M.; Vasques, L.; Soares, R. J. Cell. Biochem. 2009, 108, 1410.

26. Rocha, A.; Azevedo, I.; Soares, R. Angiogenesis 2007, 10, 279. 